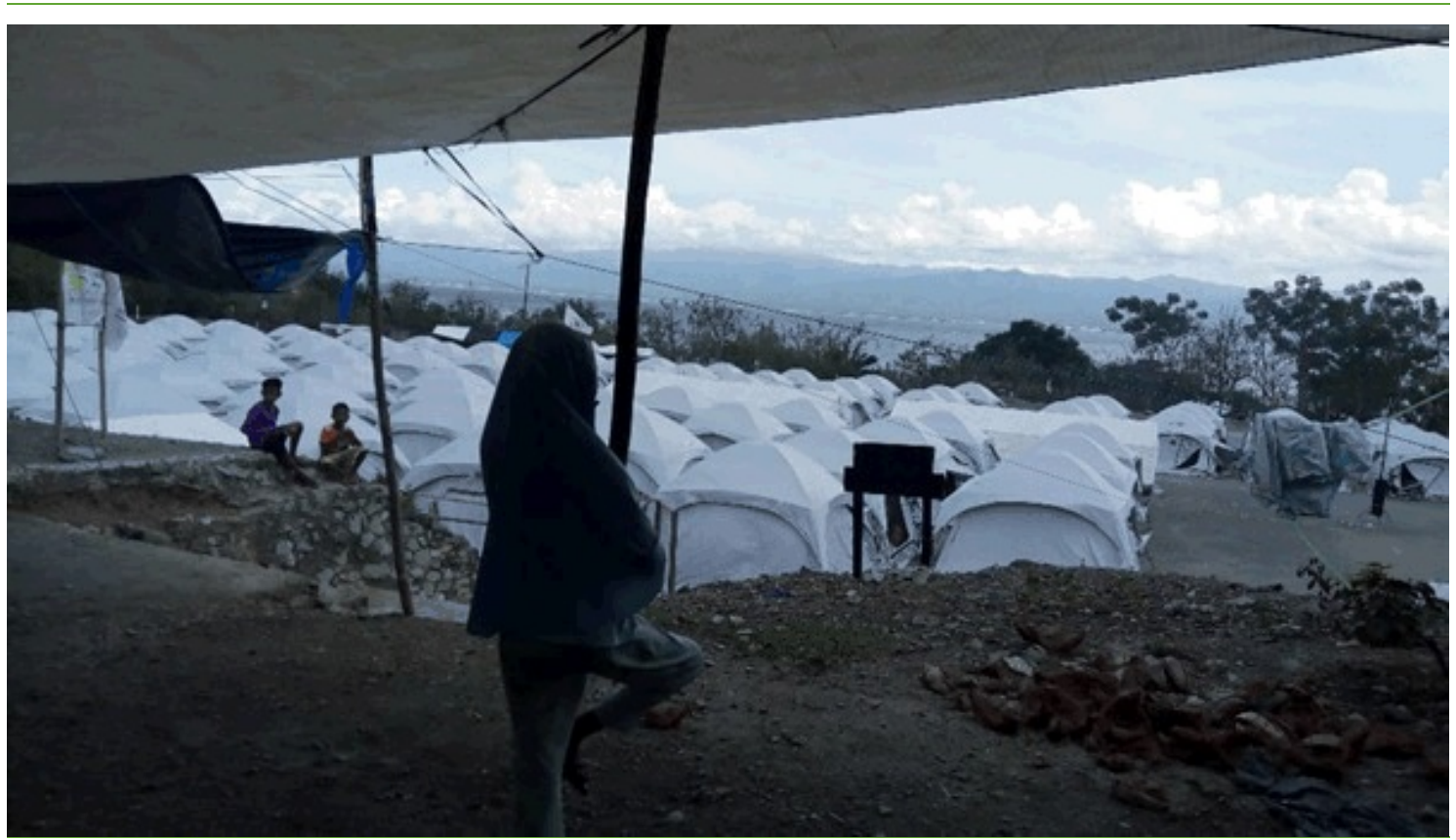

IDP canp in Loli Pesua, Banawa sub-district, in Donggala District. Photo credit: Dati Fatimah/Gender Specialist

\title{
LINGU, BOMBA TALU AND NAOMBO: TRIPLE DISASTER IN CENTRAL SULAWESI
}

\section{A gender analysis}

\section{DATI FATIMAH AND FIONA ROBERTS}

\section{GENDER CONSULTANTS}

On 28 September 2018, a major earthquake with a magnitude of 7.4 struck Central Sulawesi in Indonesia, triggering a near-field tsunami, large-scale soil liquefaction and landslides. As part of the subsequent humanitarian response, Oxfam and humanitarian networking partners JMK, including local organizations LBH APIK Palu and PKBI Palu, conducted research in camps for internally displaced persons in affected areas. The aim was to find out how the impacts of the disaster differed for women, men, boys and girls, as well as the variations in their roles and their access to and control of resources. As part of the assessment, the researchers carried out a rapid analysis of care work and also made efforts to identify how different groups might participate in the humanitarian response.

This gender analysis is based on those research findings. It makes recommendations on how to respond to immediate and life-saving practical and strategic needs, with a focus on gender. It can also be used to inform and improve future responses to similar disasters in the same geographical area.

Oxfam Research Reports are written to share research results, to contribute to public debate and to invite feedback on development and humanitarian policy and practice. They do not necessarily reflect Oxfam policy positions. The views expressed are those of the author and not necessarily those of Oxfam.

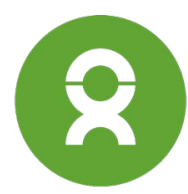




\section{CONTENTS}

Acronyms 3

Executive Summary 4

1 Introduction 11

1.1 Key objectives of the gender analysis $\quad 11$

2 Methodology 12

2.1 Rapid gender analysis: methodology -data collection methods 12

2.2 Rapid gender analysis: sampling 12

2.3 Rapid gender analysis: challenges and limitations 13

3 Pre-emergency gender profile $\quad 14$

4 Findings of the gender analysis $\quad 17$

4.1 Sex-, age-and disability-disaggregated data (SADDD) 17

$\begin{array}{ll}4.2 \text { People living with disabilities } & 17\end{array}$

$\begin{array}{ll}4.3 \mathrm{LGBTI} \text { people } & 18\end{array}$

$\begin{array}{ll}\text { 4.4 Other groups with specific vulnerabilities } & 18\end{array}$

$\begin{array}{ll}4.5 \text { Rapid care analysis } & 18\end{array}$

5 Gender issues in individual sectors 25

5.1 Gender issues in the WASH sector 25

5.2 Gender issues in the livelihoods sector 26

5.3 Gender issues in the shelter sector 29

5.4 Gender issues in the food security sector 29

5.5 Gender issues in the education sector 30

5.6 Gender issues in the health sector $\quad 31$

5.7 Gender issues in the protection sector 31

5.8 Gender issues in the camp management sector 33

6 Conclusions and recommendations $\quad 35$

Appendices $\quad 42$

Appendix 1: Summary of key research areas, tool and methods used 42

Appendix 2: Case studies of people with disabilities $\quad 43$

Appendix 3: Detailed results of rapid care analysis $\quad 44$

Notes 50

Acknowledgements 52 


\section{ACRONYMS}

BNPB

CSO

DRR

GBV

GDI

FGD

$\mathrm{HDI}$

IDP

LBH APIK

LGBTI

M\&E

NGO

PDAM

PKBI

PLN

PLTU

PMI

PNPM

SADDD

UNDP

WASH
Badan Nasional Penanggulangan Bencana (National Agency for Disaster Management)

Civil society organization

Disaster risk reduction

Gender-based violence

Gender Development Index

Focus group discussion

Human Development Index

Internally displaced person

Legal Aid Institute of the Association of Indonesian Women for Justice

Lesbian, gay, bisexual, transgender, intersex

Monitoring and evaluation

Non-governmental organization

Perusahaan Daerah Air Minum (regional water supply company)

Indonesian Planned Parenthood Federation

Perusahaan Listrik Negara (state electricity company)

Pembangkit Listrik Tenaga Uap (local steam power plant electricity company)

Palang Merah Indonesia (Indonesian Red Cross)

Program Nasional Pemberdayaan Masyarakat (National Programme for Community Empowerment)

Sex-, age- and disability-disaggregated data

United Nations Development Programme

Water, sanitation and hygiene 


\section{EXECUTIVE SUMMARY}

On 28 September 2018, a major earthquake (lingu in the local language) with a magnitude of 7.4 struck Central Sulawesi in Indonesia, triggering a near-field tsunami (bomba talu), large-scale soil liquefaction (naombo) and landslides. As of 22 October 2018, 2,081 fatalities had been reported in the province, with an estimated 4,438 people seriously injured and 206,494 displaced from their homes. ${ }^{1}$

Oxfam conducted a gender assessment in camps for internally displaced persons (IDPs) in affected areas to find out how the impacts of the disaster differed for women, men, boys and girls, and how their roles and their access to and control of resources differed. It also sought to identify the capacities of the different groups for participating in the response, as well as carrying out a rapid care analysis. Based on the findings, this gender analysis makes specific recommendations in order to respond to immediate and life-saving practical and strategic needs, with a focus on gender. This document can also be used to inform and improve future responses to similar disasters in the same geographical area.

The key findings are presented in the table below, together with recommendations aimed at the main actors involved in the response.

\begin{tabular}{|c|c|c|c|}
\hline & Key findings & Actor & Recommendations \\
\hline \multirow[t]{6}{*}{$\begin{array}{l}\text { All sectors/ } \\
\text { general } \\
\text { recommendations }\end{array}$} & \multirow[t]{2}{*}{$\begin{array}{l}\text { Women in particular are } \\
\text { facing an increased time } \\
\text { burden as a result of having } \\
\text { to spend more time on } \\
\text { WASH activities. }\end{array}$} & $\begin{array}{l}\text { Government of } \\
\text { Indonesia, UN and } \\
\text { non-governmental } \\
\text { organizations } \\
\text { (NGOs)/civil society } \\
\text { organizations (CSOs) }\end{array}$ & $\begin{array}{l}\text { WASH sector NGOs should prioritize } \\
\text { interventions that reduce the time people } \\
\text { need to spend on these activities. } \\
\text { All other sectors should ensure that } \\
\text { activities do not create an additional time } \\
\text { burden for women and that they are } \\
\text { designed to enable women's participation, } \\
\text { e.g. by offering childcare options. }\end{array}$ \\
\hline & & Donors & $\begin{array}{l}\text { Donors should ensure that funding is } \\
\text { allocated and is flexible enough to enable } \\
\text { women to participate in economic } \\
\text { activities, e.g. by providing childcare } \\
\text { facilities. Women could also be paid to } \\
\text { provide childcare services themselves. }\end{array}$ \\
\hline & \multirow{4}{*}{$\begin{array}{l}\text { There are few official sex- } \\
\text { and age-disaggregated } \\
\text { data (SADDD) available. } \\
\text { Such data are essential not } \\
\text { only for understanding } \\
\text { humanitarian needs but } \\
\text { also for showing that there } \\
\text { is a rights-based approach, } \\
\text { where all individuals are } \\
\text { respected. }\end{array}$} & Government & $\begin{array}{l}\text { Official data should always be } \\
\text { disaggregated by sex, age and disability. } \\
\text { This will enable all actors to use } \\
\text { government data to plan a more effective } \\
\text { response that meets the needs of all } \\
\text { women, men, boys and girls. }\end{array}$ \\
\hline & & UN & $\begin{array}{l}\text { UN agencies should work with the national } \\
\text { government to ensure the collection of } \\
\text { SADDD as quickly as possible. }\end{array}$ \\
\hline & & Donors & $\begin{array}{l}\text { Donors should insist on the use of SADDD in } \\
\text { the design of any programmes they fund, } \\
\text { and should budget for the collection of } \\
\text { SADDD throughout the response. }\end{array}$ \\
\hline & & NGOs/CSOs & $\begin{array}{l}\text { NGOs should use all SADDD available and } \\
\text { collect their own data where possible. } \\
\text { Where official SADDD are not available, } \\
\text { NGOs should derive estimates statistically } \\
\text { based on data available (for examples, see }\end{array}$ \\
\hline
\end{tabular}




\begin{tabular}{|c|c|c|}
\hline & & $\begin{array}{l}\text { IASC (2017). The Gender Handbook for } \\
\text { Humanitarian Action }{ }^{2} \text {. }\end{array}$ \\
\hline \multirow{3}{*}{$\begin{array}{l}\text { There was a high rate of } \\
\text { child marriage before the } \\
\text { emergency. More research } \\
\text { is needed to find whether } \\
\text { families are resorting more } \\
\text { frequently to this common } \\
\text { cultural practice as a } \\
\text { negative coping strategy. }\end{array}$} & Government & $\begin{array}{l}\text { The government should collect data on the } \\
\text { incidence of child marriage to ensure that } \\
\text { it is not being used as a negative coping } \\
\text { strategy. Economic opportunities should } \\
\text { be targeted towards very poor families. }\end{array}$ \\
\hline & UN & $\begin{array}{l}\text { UNICEF and other UN agencies should } \\
\text { include child marriage prevention } \\
\text { strategies in their programming such as } \\
\text { awareness raising on the impacts of child } \\
\text { marriage. }\end{array}$ \\
\hline & NGOs/CSOs & $\begin{array}{l}\text { NGOs, especially those that are child- } \\
\text { focused should include the prevention of } \\
\text { child marriage in their response } \\
\text { programmes and should advocate for } \\
\text { economic opportunities for the poorest } \\
\text { families. }\end{array}$ \\
\hline \multirow[t]{3}{*}{$\begin{array}{l}\text { Pre-emergency data } \\
\text { indicate increasing } \\
\text { numbers of people with } \\
\text { disabilities in the } \\
\text { province. }{ }^{3,4} \text { Further } \\
\text { research is needed to see if } \\
\text { numbers have increased } \\
\text { post-disaster. }\end{array}$} & Government & $\begin{array}{l}\text { Efforts should be made to obtain more } \\
\text { accurate data on the number of men, } \\
\text { women, boys and girls with disabilities } \\
\text { following the disaster to ensure that all } \\
\text { response activities are adapted to their } \\
\text { needs: e.g. WASH facilities are fitted with } \\
\text { appropriate supports for specific } \\
\text { disabilities found in each camp. }\end{array}$ \\
\hline & UN & $\begin{array}{l}\text { The UN should support the collection of } \\
\text { data on people with disabilities post- } \\
\text { disaster (disaggregated by sex and age). }\end{array}$ \\
\hline & NGOs/CSOs & $\begin{array}{l}\text { NGOs working with people with disabilities } \\
\text { should share any data they have with all } \\
\text { sectors, so that all areas of the response } \\
\text { can adapt to the needs of disabled people. }\end{array}$ \\
\hline \multirow{3}{*}{$\begin{array}{l}\text { The gender gap las } \\
\text { measured by UNDP's Gender } \\
\text { Development Index (GDI)) } \\
\text { was already worsening } \\
\text { before the disaster. It has } \\
\text { most probably worsened } \\
\text { still further as a result of } \\
\text { the disaster, although } \\
\text { further research is needed } \\
\text { to verify this. }\end{array}$} & Government & $\begin{array}{l}\text { The government should consider scaling } \\
\text { up the response and should have a clear } \\
\text { strategy for recovery that includes poverty } \\
\text { reduction. Specific targeting should be } \\
\text { considered to increase women's } \\
\text { empowerment to, at a minimum, avoid } \\
\text { widening the gender gap. }\end{array}$ \\
\hline & Donors & $\begin{array}{l}\text { Donors should insist that proposals } \\
\text { include a clear long-term recovery plan } \\
\text { that aims to be transformative by tackling } \\
\text { pre-existing gender inequalities. }\end{array}$ \\
\hline & NGOs/CSOs & $\begin{array}{l}\text { NGOs should have clear sustainability } \\
\text { strategies which ensure that their } \\
\text { responses contribute to reducing gender } \\
\text { inequality in the long term, and at a } \\
\text { minimum do no harm. }\end{array}$ \\
\hline $\begin{array}{l}\text { Communities have little } \\
\text { information on disaster risk } \\
\text { and preparedness, and } \\
\text { women's knowledge is more } \\
\text { limited than that of men. } \\
\text { Teenagers and children also } \\
\text { have little knowledge. Older } \\
\text { people in the community }\end{array}$ & $\begin{array}{l}\text { Government, UN, } \\
\text { donors and } \\
\text { NGOs/CSOs }\end{array}$ & $\begin{array}{l}\text { Government agencies and all actors } \\
\text { involved in longer-term recovery in Central } \\
\text { Sulawesi need to invest in disaster risk } \\
\text { reduction (DRR) measures, drawing on } \\
\text { lessons learned from the current situation. } \\
\text { They need to learn how to operationalize } \\
\text { measures at the household level, focusing } \\
\text { on women and young people and }\end{array}$ \\
\hline
\end{tabular}




\begin{tabular}{|c|c|c|c|}
\hline & $\begin{array}{l}\text { have some knowledge from } \\
\text { past disasters. }\end{array}$ & & $\begin{array}{l}\text { harnessing the knowledge of older men } \\
\text { and women. }\end{array}$ \\
\hline \multirow[t]{7}{*}{ WASH } & $\begin{array}{l}\text { Although adequate drinking } \\
\text { water is available in IDP } \\
\text { camps, the quantity of } \\
\text { clean water available does } \\
\text { not meet all the needs of } \\
\text { the population, who are } \\
\text { having to resort to unsafe } \\
\text { water sources such as } \\
\text { rivers for bathing, washing } \\
\text { clothes and defecation. } \\
\text { Alternative water sources } \\
\text { do not meet standards for } \\
\text { distances between } \\
\text { settlements and WASH } \\
\text { facilities, and this } \\
\text { increases the time burden, } \\
\text { especially for women. }\end{array}$ & $\begin{array}{l}\text { Government, UN, } \\
\text { donors, NGOs/CSOs }\end{array}$ & $\begin{array}{l}\text { This practical need must be addressed } \\
\text { urgently in the response by all WASH actors } \\
\text { in order to meet the Sphere Minimum } \\
\text { Standards. According to Indonesia's } \\
\text { Ministry of Health (in line with Sphere), the } \\
\text { minimum standard for clean water needs in } \\
\text { an emergency is } 15 \text { litres per person per } \\
\text { day, and WASH facilities should be located } \\
\text { a maximum of } 500 \text { metres from the } \\
\text { settlement. There should be at least one } \\
\text { toilet for a maximum of } 80-100 \text { people, } \\
\text { with queuing time no longer than } 15 \\
\text { minutes. } \\
\text { All those involved in the WASH sector need } \\
\text { to ensure that they play an active role and } \\
\text { are accountable for ensuring that } \\
\text { standards are met. }\end{array}$ \\
\hline & \multirow[t]{2}{*}{$\begin{array}{l}\text { Related to the lack of } \\
\text { adequate water supply, } \\
\text { protection (in particular } \\
\text { gender-based violence } \\
\text { (GBV)) and health risks } \\
\text { mean that people are using } \\
\text { unsafe sources such as } \\
\text { rivers. }\end{array}$} & Government & $\begin{array}{l}\text { This issue needs to be addressed by } \\
\text { ensuring that facilities in camps are } \\
\text { adequate for all needs relating to WASH } \\
\text { (drinking, washing clothes, bathing), so } \\
\text { that people do not need to resort to using } \\
\text { rivers or neighbours' facilities. The Ministry } \\
\text { of Health needs to ensure that it is } \\
\text { monitoring for and treating water-borne } \\
\text { diseases. The Ministry of Women's } \\
\text { Empowerment and Child Protection should } \\
\text { ensure that women and girls are not at risk } \\
\text { of GBV when accessing water sources. }\end{array}$ \\
\hline & & $\begin{array}{l}\text { UN, donors, } \\
\text { NGOs/CSOs }\end{array}$ & $\begin{array}{l}\text { The WASH sector should advocate for clean } \\
\text { water supplies as soon as possible to } \\
\text { avoid the risks involved in accessing } \\
\text { alternative sources. The sector needs to } \\
\text { be accountable for ensuring that WASH } \\
\text { facilities meet the practical needs of the } \\
\text { affected population and also meet } \\
\text { protection standards. }\end{array}$ \\
\hline & \multirow[t]{4}{*}{$\begin{array}{l}\text { There are protection risks } \\
\text { (GBV) due to inadequate } \\
\text { lighting in some WASH } \\
\text { facilities. }\end{array}$} & Government & $\begin{array}{l}\text { Ensure adequate lighting and privacy at all } \\
\text { WASH facilities and complement lighting } \\
\text { with increased security patrols, } \\
\text { appropriate design parameters and } \\
\text { reporting mechanisms for incidents of GBV. }\end{array}$ \\
\hline & & UN & $\begin{array}{l}\text { Responsibility for the monitoring and } \\
\text { evaluation (M\&E), funding and } \\
\text { maintenance of lighting at WASH facilities } \\
\text { should be agreed at WASH cluster } \\
\text { meetings. }\end{array}$ \\
\hline & & Donors & $\begin{array}{l}\text { Ensure that budgets include adequate } \\
\text { funds for lighting WASH facilities. }\end{array}$ \\
\hline & & NGOs/CSOs & $\begin{array}{l}\text { Consider testing the effects of improved } \\
\text { lighting with a study to gauge changes in } \\
\text { perceptions of safety before and after } \\
\text { lighting is installed. } 6\end{array}$ \\
\hline
\end{tabular}




\begin{tabular}{|c|c|c|c|}
\hline \multirow[t]{2}{*}{ Food security } & \multirow{2}{*}{$\begin{array}{l}\text { There is a risk of food } \\
\text { insecurity for men, women, } \\
\text { boys and girls when food } \\
\text { aid ends. With increased } \\
\text { food insecurity, the } \\
\text { affected population may } \\
\text { turn to negative coping } \\
\text { strategies (such as taking } \\
\text { out high-interest loans and } \\
\text { resorting to child marriage), } \\
\text { which usually affect women } \\
\text { and children more. More } \\
\text { research is needed to } \\
\text { identify what coping } \\
\text { strategies have been } \\
\text { adopted in this context. }\end{array}$} & Government & $\begin{array}{l}\text { The government must reconsider the } \\
\text { ending of food aid if no alternatives are in } \\
\text { place to ensure that basic needs are being } \\
\text { met. }\end{array}$ \\
\hline & & $\begin{array}{l}\text { UN, donors and } \\
\text { NGOs/CSOs }\end{array}$ & $\begin{array}{l}\text { The UN, donors and NGOs must work with } \\
\text { the government to ensure that a } \\
\text { comprehensive food security strategy is in } \\
\text { place to make sure that families do not } \\
\text { resort to damaging coping strategies. This } \\
\text { should link to a livelihoods recovery } \\
\text { strategy that takes into account and } \\
\text { values equally the contributions of women } \\
\text { and men to the economy lincluding the } \\
\text { care economy). }\end{array}$ \\
\hline \multirow[t]{6}{*}{ Livelihoods } & $\begin{array}{l}\text { Women have lost their } \\
\text { livelihoods, which were } \\
\text { largely home-based or } \\
\text { related to cleaning and } \\
\text { selling fish. Some women } \\
\text { have taken out high- } \\
\text { interest loans to restart } \\
\text { their businesses. }\end{array}$ & $\begin{array}{l}\text { Government, UN, } \\
\text { donors, NGOs/CSOs }\end{array}$ & $\begin{array}{l}\text { Livelihood actors should consult with } \\
\text { women in order to establish the best } \\
\text { mechanisms to meet their food security } \\
\text { needs and to re-establish livelihood } \\
\text { activities. }\end{array}$ \\
\hline & $\begin{array}{l}\text { Men have lost their } \\
\text { livelihoods as they have } \\
\text { lost their boats and fishing } \\
\text { equipment. However, } \\
\text { fishing was already under } \\
\text { threat before the disaster. }\end{array}$ & $\begin{array}{l}\text { Government, UN, } \\
\text { donors, NGOs/CSOs }\end{array}$ & $\begin{array}{l}\text { Further analysis and consultation are } \\
\text { needed with men and women by all } \\
\text { livelihood sector actors to decide the best } \\
\text { course of action to recover livelihoods. } \\
\text { Analysis is needed to establish whether } \\
\text { restoring fishing livelihoods is the most } \\
\text { appropriate course of action, or whether a } \\
\text { livelihoods diversification strategy would } \\
\text { be more appropriate. }\end{array}$ \\
\hline & \multirow[t]{4}{*}{$\begin{array}{l}\text { There is a pre-existing } \\
\text { societal belief that women } \\
\text { are secondary livelihood } \\
\text { providers in the household. }\end{array}$} & Government & $\begin{array}{l}\text { Any livelihood programmes established } \\
\text { should include campaign activities with } \\
\text { men and women to increase the value } \\
\text { attributed to women's work (both } \\
\text { reproductive and productive) in order to } \\
\text { challenge gender norms. Leadership by } \\
\text { women should be encouraged in all } \\
\text { livelihood activities. }\end{array}$ \\
\hline & & UN & $\begin{array}{l}\text { The UN should work with the government to } \\
\text { design a long-term livelihood programme } \\
\text { that seeks to promote women's leadership } \\
\text { and to change societal beliefs around the } \\
\text { role of women. }\end{array}$ \\
\hline & & Donors & $\begin{array}{l}\text { Donors should ensure that actions are } \\
\text { included in any livelihoods proposals to } \\
\text { counteract negative beliefs and to } \\
\text { promote women's leadership. }\end{array}$ \\
\hline & & NGOs/CSOs & $\begin{array}{l}\text { NGOs and CSOs should pilot women's } \\
\text { empowerment programmes in the } \\
\text { livelihoods sector that can then be taken } \\
\text { up by the government and scaled up. } \\
\text { Campaigns working with men and women } \\
\text { to change views on gender norms should } \\
\text { also be undertaken. NGOs can work with } \\
\text { village leaders to promote gender equality. }\end{array}$ \\
\hline
\end{tabular}




\begin{tabular}{|c|c|c|c|}
\hline \multirow[t]{9}{*}{ Shelter } & $\begin{array}{l}\text { Cold conditions have been } \\
\text { reported in shelters at } \\
\text { night. }\end{array}$ & $\begin{array}{l}\text { Government, UN, } \\
\text { donors, NGOs/CSOs }\end{array}$ & $\begin{array}{l}\text { Consider distributions of blankets and } \\
\text { improvements to shelters that take into } \\
\text { consideration the different needs of men, } \\
\text { women, girls and boys. }\end{array}$ \\
\hline & $\begin{array}{l}\text { Each tent is shared by } 2-3 \\
\text { families, without any } \\
\text { partitions to separate one } \\
\text { family from another. }\end{array}$ & $\begin{array}{l}\text { Government, UN, } \\
\text { NGOs/CSOs }\end{array}$ & $\begin{array}{l}\text { Erect partitions in tents and promote } \\
\text { privacy. Invest in earthquake-proof } \\
\text { shelters, with co-ownership by wives and } \\
\text { husbands of any shelter scheme. }\end{array}$ \\
\hline & \multirow{4}{*}{$\begin{array}{l}\text { Inadequate lighting around } \\
\text { shelters represents a GBV } \\
\text { risk and makes women and } \\
\text { girls feel unsafe. }\end{array}$} & Government & $\begin{array}{l}\text { Urgently install adequate lighting around } \\
\text { all shelters. }\end{array}$ \\
\hline & & UN & $\begin{array}{l}\text { Clarify who is responsible for monitoring } \\
\text { and evaluating lighting around shelters. }\end{array}$ \\
\hline & & Donors & $\begin{array}{l}\text { Ensure that budgets for shelter include } \\
\text { sufficient lighting. }\end{array}$ \\
\hline & & NGOs/CSOs & $\begin{array}{l}\text { Monitor and evaluate perceptions of GBV } \\
\text { risk (and reported cases) before and after } \\
\text { improved lighting is installed. }\end{array}$ \\
\hline & $\begin{array}{l}\text { The affected population are } \\
\text { not actively participating in } \\
\text { shelter construction. }\end{array}$ & $\begin{array}{l}\text { Government, UN, } \\
\text { donors, NGOs/CSOs }\end{array}$ & $\begin{array}{l}\text { Actively promote participation by the } \\
\text { affected population (women and men) in } \\
\text { shelter design and construction. }\end{array}$ \\
\hline & $\begin{array}{l}\text { In some cases, the building } \\
\text { of shelters has created } \\
\text { further risk e.g. in } \\
\text { Langaleso shelters have } \\
\text { been built on rice fields } \\
\text { prone to flooding. }\end{array}$ & $\begin{array}{l}\text { Government, UN, } \\
\text { donors, NGOs/CSOs }\end{array}$ & $\begin{array}{l}\text { Incorporate a comprehensive DRR strategy } \\
\text { into the shelter response, ensuring that } \\
\text { shelters are earthquake- and flood- } \\
\text { resistant. }\end{array}$ \\
\hline & $\begin{array}{l}\text { The tents provided are not } \\
\text { friendly spaces for pregnant } \\
\text { and breastfeeding women } \\
\text { or for women and men with } \\
\text { disabilities. }\end{array}$ & $\begin{array}{l}\text { Government, UN, } \\
\text { donors, NGOs/CSOs }\end{array}$ & $\begin{array}{l}\text { Create spaces in the camps that are } \\
\text { friendly to women and to people with } \\
\text { disabilities, in consultation with these } \\
\text { groups to ensure appropriate location and } \\
\text { services. Women and people living with } \\
\text { disabilities should also be involved in the } \\
\text { management of these spaces. }\end{array}$ \\
\hline \multirow[t]{4}{*}{ Education } & $\begin{array}{l}\text { There is little psychosocial } \\
\text { support available, and } \\
\text { teachers are having to take } \\
\text { on this role. }\end{array}$ & $\begin{array}{l}\text { Government, UN, } \\
\text { donors and NGOs }\end{array}$ & $\begin{array}{l}\text { Psychosocial support needs to be provided } \\
\text { for school children and teachers, and } \\
\text { teachers should be trained on how to } \\
\text { provide this support to their students. }\end{array}$ \\
\hline & \multirow[t]{3}{*}{$\begin{array}{l}\text { High daytime temperatures } \\
\text { in tents make it hard for } \\
\text { children to study. } \\
\text { Temporary schools are still } \\
\text { in use. }\end{array}$} & Government & $\begin{array}{l}\text { Ensure that tents are set up with adequate } \\
\text { ventilation and that teachers are clear on } \\
\text { how to use ventilation systems. If } \\
\text { necessary, adjust school hours to cooler } \\
\text { times of the day, in consultation with } \\
\text { affected communities. In the long term, the } \\
\text { Ministry of Education needs to invest in } \\
\text { earthquake-proof school buildings and in } \\
\text { strategies to promote safety in schools. } \\
\text { Schools should have adequate menstrual } \\
\text { hygiene facilities to encourage attendance } \\
\text { by girls. }\end{array}$ \\
\hline & & UN & $\begin{array}{l}\text { The UN should support the government in } \\
\text { the rebuilding of earthquake-proof schools } \\
\text { that take into account the needs of both } \\
\text { girls and boys. }\end{array}$ \\
\hline & & NGOs/CSOs & $\begin{array}{l}\text { Where NGOs are providing temporary } \\
\text { schools, they should ensure that } \\
\text { ventilation is adequate and should }\end{array}$ \\
\hline
\end{tabular}




\begin{tabular}{|c|c|c|c|}
\hline & & & $\begin{array}{l}\text { advocate for the rebuilding of permanent } \\
\text { schools. }\end{array}$ \\
\hline \multirow[t]{7}{*}{ Health } & \multirow[t]{4}{*}{$\begin{array}{l}\text { There is a lack of } \\
\text { reproductive health } \\
\text { services in the camps; } \\
\text { basic healthcare is } \\
\text { available, but not } \\
\text { reproductive healthcare. }\end{array}$} & Government & $\begin{array}{l}\text { The government should ensure that } \\
\text { reproductive health services are prioritized } \\
\text { in the response, and should work with } \\
\text { existing health services in the camps to } \\
\text { ensure that they also take into account } \\
\text { reproductive health needs. }\end{array}$ \\
\hline & & UN & $\begin{array}{l}\text { The UN should consider stepping in to fill } \\
\text { the gap while services are being } \\
\text { established. }\end{array}$ \\
\hline & & Donors & $\begin{array}{l}\text { Donors in the health sector should ensure } \\
\text { that funds are earmarked for reproductive } \\
\text { health services. }\end{array}$ \\
\hline & & NGOs/CSOs & $\begin{array}{l}\text { NGOs/CSOs specializing in reproductive } \\
\text { health should work with existing basic } \\
\text { health services to establish why } \\
\text { reproductive health services are not } \\
\text { available, and help provide a solution. }\end{array}$ \\
\hline & \multirow{3}{*}{$\begin{array}{l}\text { Psychosocial support post- } \\
\text { trauma is not widely } \\
\text { available. This is affecting } \\
\text { people's ability to work, as } \\
\text { well as their health. }\end{array}$} & Government & $\begin{array}{l}\text { Psychosocial support should be provided in } \\
\text { all camps, ensuring that men, women, boys } \\
\text { and girls have access to services. }\end{array}$ \\
\hline & & Donors & $\begin{array}{l}\text { Donors in the health sector should ensure } \\
\text { that funds are earmarked for psychosocial } \\
\text { health services. }\end{array}$ \\
\hline & & NGOs/CSOs & $\begin{array}{l}\text { NGOs/CSOs specializing in psychosocial } \\
\text { support should fill the gap if necessary and } \\
\text { train local health centre staff in basic } \\
\text { psychosocial support. }\end{array}$ \\
\hline \multirow[t]{2}{*}{ Protection } & $\begin{array}{l}\text { GBV is a particular risk, and } \\
\text { there have been reports of } \\
\text { rape and harassment of } \\
\text { LGBTI people. There is } \\
\text { limited information about } \\
\text { women's rights, legal } \\
\text { protections and the } \\
\text { availability of paralegal } \\
\text { services. }\end{array}$ & $\begin{array}{l}\text { Government, UN, } \\
\text { donors and } \\
\text { NGOS/CSOs }\end{array}$ & $\begin{array}{l}\text { All actors involved in protection need to } \\
\text { ensure the availability of reliable GBV } \\
\text { reporting mechanisms and case referral } \\
\text { services which all women, men, boys, girls } \\
\text { and LGBTI people can access. Information } \\
\text { on women's rights, legal protections and } \\
\text { paralegal services should be } \\
\text { communicated to the affected population. }\end{array}$ \\
\hline & $\begin{array}{l}\text { There is a risk of people } \\
\text { adopting negative coping } \\
\text { strategies, such as child } \\
\text { marriage or taking out high- } \\
\text { interest loans. }\end{array}$ & $\begin{array}{l}\text { Government, UN, } \\
\text { donors and } \\
\text { NGOS/CSOs }\end{array}$ & $\begin{array}{l}\text { Further research is recommended on } \\
\text { negative coping strategies in order to } \\
\text { target at-risk groups with appropriate } \\
\text { actions. }\end{array}$ \\
\hline \multirow[t]{2}{*}{$\begin{array}{l}\text { Camp } \\
\text { management }\end{array}$} & \multirow[t]{2}{*}{$\begin{array}{l}\text { Where women do not } \\
\text { participate in camp } \\
\text { management, they tend not } \\
\text { be involved in decision } \\
\text { making. }\end{array}$} & Government & $\begin{array}{l}\text { Promote women's leadership and } \\
\text { participation in camp management, } \\
\text { working with men where necessary to raise } \\
\text { awareness of the importance and value of } \\
\text { women's participation. }\end{array}$ \\
\hline & & NGOs/CSOs & $\begin{array}{l}\text { Advocate for women's participation and } \\
\text { leadership in all camp management } \\
\text { committees. }\end{array}$ \\
\hline
\end{tabular}




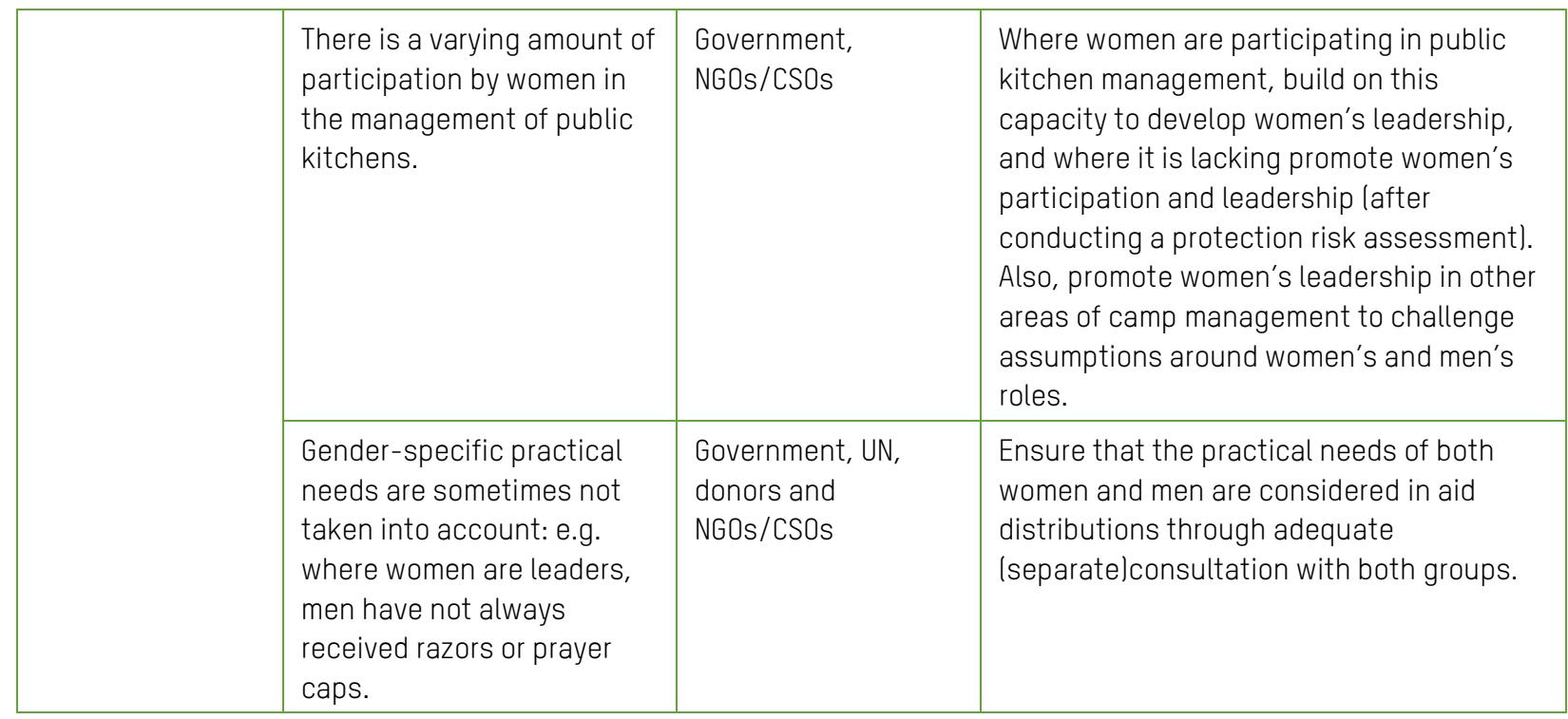


On 29 September 2018, the city of Palu, the capital of Central Sulawesi province, was hit by an earthquake (lingu in the local language) with a magnitude of 7.4 , which triggered near-field tsunami waves (bomba talu), widespread soil liquefaction (naombo) and landslides. The National Agency for Disaster Management (BNPB) reported a final death toll of 2,081 people - 1,706 people in Palu and the rest in Donggala (171), Sigi (188), Parigi Moutong (15) and Pasangkayu, West Sulawesi lone person). ${ }^{7}$ However, this was just an estimate, as many more people were reported missing and their bodies were never found. ${ }^{8}$ The disaster also resulted in the forced displacement of 206,494 people from their homes; 65,733 houses and 2,736 schools were damaged, along with 22 health facilities. Early estimates put the economic losses caused by the disaster at IDR 13.83 trillion (US $\$ 128,092,680) .{ }^{9}$ Unfortunately, none of the official data have been disaggregated by sex or age.

The areas worst affected by the disaster were Palu city and the districts of Donggala and Sigi, though some surrounding areas such as Pasangkayu and Parigi Moutong in West Sulawesi also suffered. Both urban and rural areas were affected, on the coast and inland, with settlements ranging in size from villages to towns and cities. Most of the affected population worked in agriculture as farmers or as fishermen, or ran businesses and small enterprises, and most survivors are pursuing the same livelihoods after the disaster. Some have been able to return to their houses and some are living in temporary shelters, but many remain in the camps for internally displaced persons (IDPS) set up after the disaster. Those who have not moved to temporary shelter have generally not done so because they still have land or livestock with which they can earn a living. The emergency phase is now over and the recovery phase is under way, with the government preparing to provide permanent homes for IDPs. It is expected that affected households will be able to move to permanent housing by September 2020.

Oxfam conducted a gender analysis after the disaster to investigate how its impacts differed for women, men, boys and girls and how the roles of these different groups and their access to and control over resources differed. Oxfam also sought to identify their capacities for participating in the response, as well as carrying out a rapid care analysis to understand the division of productive and reproductive work. Based on the findings, this report makes specific recommendations for different actors to respond to the immediate and life-saving practical and strategic needs of the community, with a focus on gender. This document can also be used to inform and improve future responses to similar disasters in the same geographical area.

\section{I KEY OBJECTIVES OF THE GENDER ANALYSIS}

- Identify the impacts of the disaster on women and men and boys and girls, identifying genderbased vulnerabilities.

- Identify the capacities of women and men, boys and girls to participate in post-disaster recovery activities.

- Carry out a rapid care analysis to understand the division of productive and reproductive work.

- Provide recommendations for a gender-transformative response in post-disaster recovery. 


\section{METHODOLOGY}

\subsection{RAPID GENDER ANALYSIS: METHODOLOGY-DATA COLLECTION METHODS}

The gender analysis used a combination of primary and secondary data collection methods:

- a desk review of pre- and post-disaster secondary data

- primary data collection.

Community respondents and key informants were selected from:

- communities that had been affected by multiple hazards - earthquake, tsunami and soil liquefaction

- both urban and rural areas

- areas in Central Sulawesi where Oxfam's partner organizations, the Legal Aid Institute of the Association of Indonesian Women for Justice (LBH APIK) and the Indonesian Planned Parenthood Federation(PKBI), were working on the humanitarian response.

The research team ensured that vulnerable groups were represented, including:

- female-headed households, girls, elderly women, persons with disabilities, women with a family member with a disability, religious and ethnic groups.

The following data collection methods were used:

- focus group discussions (FGDs)/group interviews, carried out separately with women and men, girls and boys

- in-depth interviews conducted with key informants, including LGBTI people and people living with disabilities

- direct observation in the community.

The primary data collection was carried out in the period10-16 November 2018. For more details on the key research areas and the tools used, see Appendix 1.

\subsection{RAPID GENDER ANALYSIS: SAMPLING}

Table 1: Rapid gender analysis sampling

\begin{tabular}{|l|l|l|}
\hline Area/partner & $\begin{array}{l}\text { LBH APIK (Legal Aid Institute of the Association of } \\
\text { Indonesian Women for Justice) }\end{array}$ & $\begin{array}{l}\text { PKBI (Indonesian Planned Parenthood } \\
\text { Federation) }\end{array}$ \\
\hline Palu & $\begin{array}{l}\text { Pacuan Kuda, Tawaeli, East Palu } \\
\text { - Affected by earthquake and tsunami } \\
\text { - Urban } \\
\text { FGD and data collection carried out on 12 } \\
\text { November and follow-up a few days later }\end{array}$ & $\begin{array}{l}\text { Kabonena, West Palu } \\
\text { - Affected by earthquake and } \\
\text { liquefaction }\end{array}$ \\
\hline Sigi & $\begin{array}{l}\text { - Urban } \\
\text { Langaleso, Sigi } \\
\text { - Affected by earthquake and liquefaction } \\
\text { - Rural } 12 \text { November }\end{array}$ & \\
\hline
\end{tabular}




\begin{tabular}{|l|l|l|}
\hline \multirow{2}{*}{ Donggala } & $\begin{array}{l}\text { FGD carried out on } 11 \text { November and follow-up } \\
\text { a few days later }\end{array}$ & \\
& & $\begin{array}{l}\text { Loli Pesua } \\
\text { - Affected by earthquake and } \\
\text { tsunami }\end{array}$ \\
& $\begin{array}{l}\text { Rural } \\
\text { - FGD and data collection carried out } \\
\text { on 13 November and follow-up a few } \\
\text { days later }\end{array}$ \\
\hline & \\
& & \\
\hline
\end{tabular}

\subsection{RAPID GENDER ANALYSIS: CHALLENGES AND LIMITATIONS}

The main limitation in this research was time. The affected population were occupied with their daily activities as they were still recovering from the disaster. One FGD had to be cancelled and replaced by a group interview as the affected population lacked the time to take part. This limited opportunities to confirm some of the findings and to triangulate data with official data from the local government.

Some details of the gender analysis will require further research lidentified in the 'Recommendations' section); this was not within the scope of this analysis due to the tight timeframe. 


\section{PRE-EMERGENCY GENDER PROFILE}

Gender inequalities invariably exist even before a crisis, and these pre-existing inequalities mean that women, men, boys and girls are affected in different ways when a disaster occurs due to their differing status and roles in society. These differences can affect people's access to resources and services in a crisis, potentially exacerbating pre-existing inequalities. ${ }^{10}$ However, a crisis may also offer a window of opportunity to change gender roles in order to reduce inequality in the future. It is therefore important to understand the pre-emergency gender profile of the local context in order to adapt the response to avoid worsening inequalities between women and men and, where possible, promote transformative change.

The following gender gap issues were highlighted by the provincial government of Central Sulawesi in an official publication prior to the disaster. ${ }^{11}$ Oxfam's assessment of the likely impact of the disaster in each area is contained in the bullet points.

One million people, or 35 percent of Central Sulawesi's population, are children under the age of 18 . Three out of four children live in rural areas. In 2015, more than 185,000 children (18.2 percent) were living below the provincial poverty line (set at IDR 11,127 (\$0.78) per person per day). Many more households were living only slightly above the poverty line.

- It is likely that the external shock of the disaster will have pushed families deeper into poverty, and those who were previously just above the poverty line will now have fallen below it.

In 2015, an estimated 54 per cent of women gave birth in health facilities, and 78 per cent of deliveries were attended by a well-trained professional.

Central Sulawesi has made good progress towards achieving universal primary education for all. However, children from the poorest households are 2.8 times less likely to complete secondary school compared with children from the richest households.

- If more children have been pushed into poverty as a result of the crisis, this may have a negative impact on school attendance and secondary school completion rates for the poorest children.

Based on 2015 data, one out of five women aged 20-24 had married or had lived with an intimate partner before they turned 18 . The rate of early marriage among girls from the poorest households was higher than for girls from the richest households.

- The rate of early marriage in the province was already high, and the increased levels of poverty and vulnerability caused by the disaster mean that there is a risk of this rate increasing further as a negative coping mechanism.

No specific data are available on violence against women and children in Central Sulawesi. However, data at the national level indicate that 28 percent of women and children have experienced physical, emotional or sexual abuse committed by an ex-partner or their current intimate partner.

- There is a risk that the incidence of GBV will increase due to increased levels of stress and vulnerability resulting from the disaster. This should be monitored, and adequate reporting mechanisms put in place.

Sixty per cent of households have access to clean drinking water, though a large gap exists between the poorest and richest households. While half of the population have access to basic sanitation facilities in or near their homes, a quarter still practise open defecation.

- With this being an accepted practice pre-crisis, it is likely that the incidence of open defecation will increase in the emergency setting if adequate WASH facilities and public health promotion programmes are not put in place. The associated health implications put all of the affected population at risk. 
Data from $2017^{12}$ give some important insights into the gender profile of Central Sulawesi.

The total population of the province was 2,921,715, with 1,492,152 males and 1,429,563 females. The ratio of males to females was 104.38, higher than the national ratio between the sexes (102). The two areas worst affected by the disaster had a high male-to-female sex ratio - 105.5 in Sigi and 104.9 in Donggala, while the ratio in Palu was $101 .{ }^{13}$

14.45 percent of the population of Central Sulawesi were living below the poverty line, set at IDR 375,659 (\$26.34) monthly.

The proportion of the population (15 years old and above) who were illiterate was 2.45 per cent for males and 3.98 per cent for females.

- Illiteracy is an important factor to take into account in any information sharing around service availability. Alternatives to written information should be made available to ensure access for all.

A total of 160 cases of HIV/AIDS were reported in 2016, with 94 of those cases in Palu.

- Reproductive health services should be made a priority in the response, and health programmes should ensure that antiretroviral drugs are available for HIV / AIDS patients.

In 2016, inequality of participation in the labour market was found in all age groups (broadly, men participate more than women).

Early marriage is prevalent for girls aged 10 and above: 16.33 percent of girls were married before the age of 16 , and 21.83 percent at the ages of $17-18$.

- Education programmes should monitor whether there is any increase in early marriage among the school-age population as a negative coping strategy. Prevention strategies should be considered.

The number of people with disabilities has been rising year on year, though this may be related to improved reporting. In 2016, there were 2,200 people in the province who were had impaired vision or were blind, 5,032 deaf and mute people, 7,227 people with a physical disability, 3,400 with a mental disability, 1,508 with a double disability and 2,394 suffering from chronic diseases.

- The population census carried out in 2010 showed that there were 10.6 million people in Indonesia with disabilities, or 4.5 per cent of the total population. The data indicate that the number of women with disabilities, especially those aged over 40 , is higher than the number of men with disabilities.

- The response should ensure that people living with disabilities have adequate access to services and are able to participate in activities. Data should be collected to establish if the number of people living with disabilities has increased post-disaster and if access to services has changed for people living with disabilities. 
Figure 1: People with disabilities, by age group and $\operatorname{sex}^{14}$

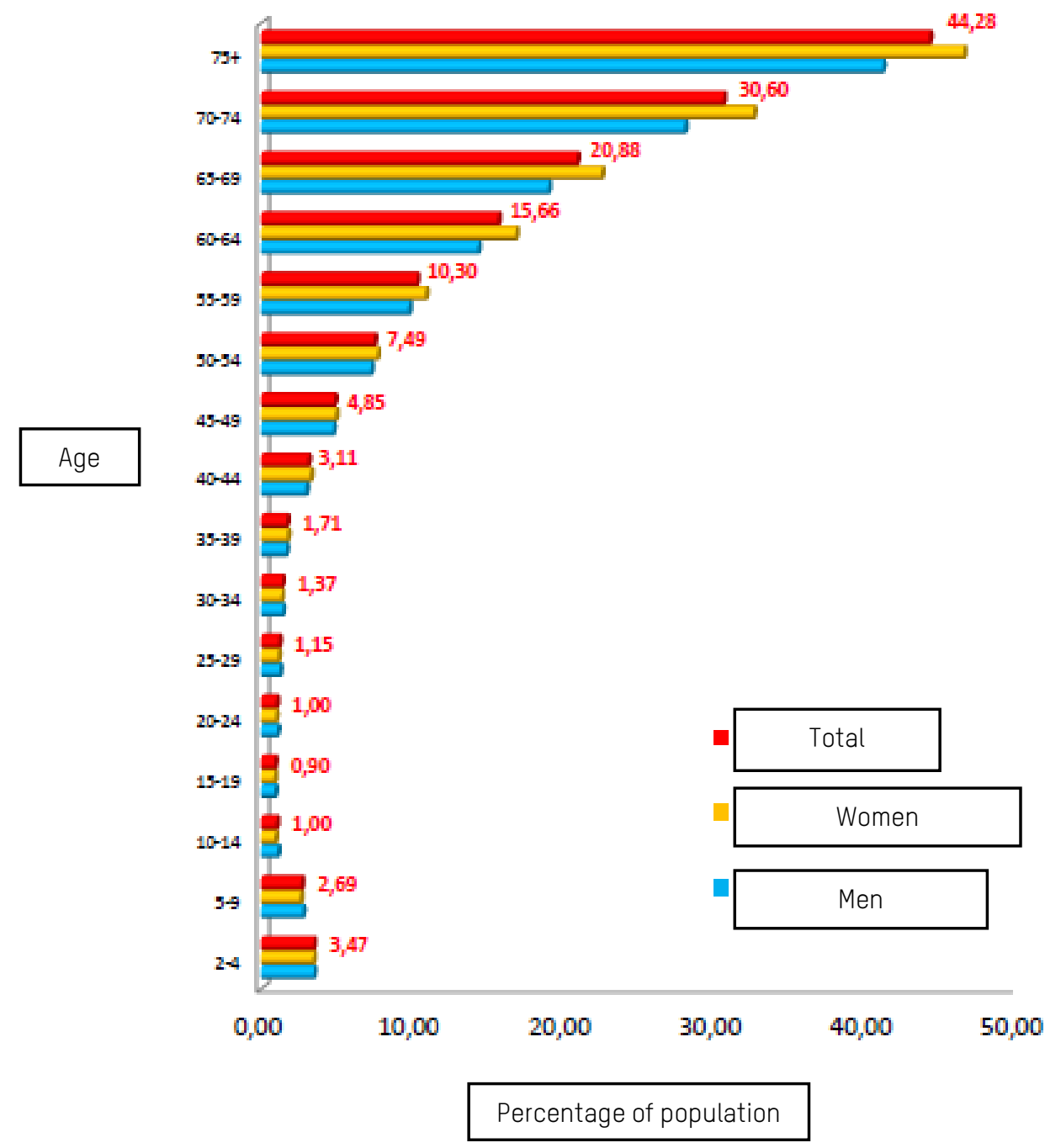

The Human Development Index (HDI)2018, published by the United Nations Development Programme (UNDP), ranks Indonesia at 116 in the world. ${ }^{15}$ The index includes the Gender Development Index (GDI), which measures different scores for males and females on the HDI in terms of health, income and education and gives an idea of how far behind females are in each area of development. In 2017, the country's GDI score was 0.932 (compared with gender parity, which is set at 100 ). ${ }^{16}$ The GDI score for Central Sulawesi stood at 0.9269in 2014 but fell to 0.9225 in2015, one of the largest GDI decreases for an Indonesian province. ${ }^{17}$ The causes of this decrease included the income gap between women and men.

During a crisis, women, girls and vulnerable groups tend to have limited access to the resources and basic services they need in order to survive and recover. In previous disasters in Indonesia the rights of children and women have not been adequately considered, and It has also been shown that disasters have increased the workload for women, as well as the incidence of violence against women and children. ${ }^{18}$

However, narratives from various disasters in the country have also testified to women's resilience when faced with a crisis. Women often serve as the backbone of the family and of their communities, providing food in public kitchens, managing limited supplies of clean water, managing community-based data and aid, informally managing resources and taking care of people who are sick or disabled. ${ }^{19}$ Unfortunately, there is little recognition of these care roles or of the contribution that women make to resource management and control in situations of post-disaster recovery. 


\section{FINDINGS OF THE GENDER ANALYSIS}

The findings of the gender analysis are organized as follows: findings relevant to all sectors - sex-, age- and disability-disaggregated data (SADD), people living with disabilities, LGBTI people and other people with specific vulnerabilities followed by the rapid care analysis (section 4.5), with findings for the latter set out for the different groups analysed, along with conclusions. Further sections then look separately at gender issues relating to each sector of the response IWASH, livelihoods, shelter, food security, education, health, protection and camp management).

\subsection{SEX-, AGE-AND DISABILITY-DISAGGREGATED DATA (SADDD)}

Very few official data disaggregated by sex, age and disability are available for this crisis. The numbers of victims are estimated, as not all bodies have been recovered. As of 220 ctober 2018, it was reported that there were 2,081 fatalities, 4,438 people seriously injured and 206,494 persons displaced from their homes. ${ }^{20}$ Data collected in the course of this research provided further details for the specific areas visited.

In the IDP camp for the village of Langaleso three casualties were reported, one man and two women, as well as one girl presumed dead (carried away by a mudslide). In Pacuan Kuda camp there were 23 casualties, seven women and 16 men, with three people (one woman and two men) still missing. Two people (sex unknown) suffered serious injuries, such as broken bones. A 30-year-old woman with a disability and two older people over 60 years of age were left paralysed after the disaster. Two primary school buildings were damaged, affecting children's access to education.

According to a man in Pacuan Kuda camp, most of the men who lost their lives died while trying to save immediate family members, relatives or neighbours. It is thought that their actions were shaped by social constructs around masculinity that led men to take risks in order to save others before saving themselves.

In Loli Pesua camp, one man (48) died from severe injuries sustained when a building collapsed; it was reported that he did not receive adequate medical care. There were no other reports of people being seriously injured in the disaster.

In Kabonena camp, it was reported that two girls (aged 12 and eight) were lost due to soil liquefaction, while one woman (41) was declared dead.

According to the Ministry of Education and Culture, in total 1,299 school buildings in Central Sulawesi were affected by the disaster:386 in Palu city, 267 in Sigi, 540 in Donggala and106 in Parigi Moutong district. ${ }^{21}$

\subsection{PEOPLE LIVING WITH DISABILITIES}

There are few official data available post-disaster on people with disabilities. However, based on an analysis of case studies collected for this research (see Appendix 2), specific vulnerabilities faced by people with disabilities in the camps include the following.

- They lack access to information on the disaster response. Many people with disabilities had already dropped out of school, and they have differing communication abilities and limited participation in the response. 
- They faced particular challenges when the disaster struck, as physical disabilities hindered their ability to reach safety. This issue must be taken into account in any future preparedness/DRR activities.

- The basic needs of people with disabilities - such as food and clothing, wheelchairs, hearing aids and glasses - have not always been considered in the response.

- Many people with disabilities have experienced exclusion by their family or neighbours, which has led to a lack of confidence, even before the disaster. Their rights to participate in social and community activities must be taken into account.

- Some young people with disabilities are at risk of GBV and sexual harassment due to their specific vulnerabilities.

\subsection{LGBTI PEOPLE}

Specific vulnerabilities faced by people identifying as LGBTI are discussed in the relevant sector sections below. However, one general point worth considering across all sectors is that the LGBTI community has shown capacity for informal organization. This has served as a support net, with LGBTI people sharing information about the disaster and mobilizing support and solidarity from other organizations. This capacity can be built on by all sectors to ensure the participation of LGBTI people in the response.

\subsection{OTHER GROUPS WITH SPECIFIC VULNERABILITIES}

Other groups with vulnerabilities participated in the analysis, including young people and femaleheaded households. The findings relating to these groups are mainstreamed throughout this document, as well as further findings on LGBTI people and people with disabilities relevant to specific sectors.

\subsection{RAPID CARE ANALYSIS}

Productive work is often considered by society to be more important than unpaid work, as it has a demonstrable economic value. Reproductive work, or the care economy - such as cleaning, cooking, washing clothes and taking care of children and those who are sick - is regarded as less significant as it usually does not have a clear economic value. Recognition of the care economy is important in a gender analysis because these jobs are closely tied to women's responsibilities and consume a significant proportion of their time and energy. Such tasks also prevent women from optimizing their potential in other productive and community roles. ${ }^{22}$ The inflexibility of genderbased roles means that men are able to invest much more time and energy in productive work as they receive support and are effectively subsidized by the care economy work done by women.

The rapid care analysis was conducted as part of the gender analysis to investigate changing dynamics in the care economy. The distribution of productive and reproductive work was analysed by comparing daily calendars for men and women before and after the disaster. Daily calendars were compiled separately for men and women in the different camps. The findings are summarized below; the details of each analysis are presented in Appendix 3.

\subsubsection{Men's activities}

The analysis of time allocations for different activities in Kabonena, Palu showed that men's activities before the disaster consisted largely of work, personal activities and rest. There was little change in the time allocations for these activities after the disaster; however, men have taken on 
some additional roles related to social work, such as sharing workloads in the camp and undertaking watch duty at night to secure the camp or the kampong (village). This system of watchkeeping (known as siskamling) existed before the disaster and was undertaken by adult male heads of household; following the disaster, they have also been on the alert for aftershocks. Men allocated no time to reproductive work, either before or after the disaster.

A similar daily activity cycle and time allocation was found at Loli Pesua camp, where men's activities consisted mainly of working, enjoying leisure time and social activities. Since the disaster, they have spent more time socializing with their peers. Men who are unemployed often spend their whole day at the camp waiting for information about aid. It is interesting to note that men claimed that before the disaster they helped take their children to school before going to work. However, this is not the case in the camp: women now perform this task, or sometimes children stay at home due to the trauma they have experienced.

For men in Langaleso camp, activities before the disaster were predominantly productive work, personal time and rest. After the disaster, men have had much more free time as they are now unemployed. They mostly dig in the ruins of buildings in search of zinc sheeting to sell, spend time at the camp to access information on aid, and rest. It is interesting to note that, after the disaster, most men claimed that they helped their wives look for firewood for cooking.

Meanwhile at Pacuan Kuda camp men now focus on productive work, personal and social activities and rest. Before the disaster, most men in this camp worked either as fishermen or at the Pembangkit Listrik Tenaga Uap (PLTU) steam-powered thermal powerplant. Fisherman usually went to sea at $5 \mathrm{am}$ and returned home at $1 \mathrm{lam}$. Women then cleaned the fish caught by their husbands and sold it at the market. PLTU staff usually worked eight-hour shifts: the morning shift was from $8 \mathrm{am}$ to $4 \mathrm{pm}$, the evening shift from $4 \mathrm{pm}$ to $11 \mathrm{pm}$ and the night shift from $11 \mathrm{pm}$ to $8 \mathrm{am}$.

Table 2 summarizes men's time allocations, based on different categories of activity, before and after the disaster. 
Table 2: Summary of time use analysis for men, before and after the disaster

\begin{tabular}{|c|c|c|c|c|c|}
\hline \multirow[t]{2}{*}{ Camp } & \multirow[t]{2}{*}{ Activity category } & \multicolumn{2}{|c|}{ Before the disaster } & \multicolumn{2}{|c|}{ After the disaster } \\
\hline & & Time (hours) & $\%$ & Time (hours) & $\%$ \\
\hline \multirow[t]{4}{*}{ Pacuan Kuda } & Productive work & 5 & $21 \%$ & 2 & $8.3 \%$ \\
\hline & Reproductive/domestic & 0 & $0 \%$ & 0 & $0 \%$ \\
\hline & Community/social & 3 & $12.5 \%$ & 6 & $25 \%$ \\
\hline & Rest and personal & 16 & $67 \%$ & 16 & $67 \%$ \\
\hline \multirow[t]{4}{*}{ Kabonena } & Productive work & 10 & $42 \%$ & 0 & 0 \\
\hline & Reproductive/domestic & 2 & $8 \%$ & 2 & $8 \%$ \\
\hline & Community/social & 3 & $13 \%$ & 10 & $42 \%$ \\
\hline & Rest and personal & 9 & $38 \%$ & 12 & $50 \%$ \\
\hline \multirow[t]{4}{*}{ Langaleso } & Productive work & 7.5 & $31 \%$ & 0 & 0 \\
\hline & Reproductive/domestic & 0 & 0 & 3 & $12 \%$ \\
\hline & Community/social & 6 & $25 \%$ & 10.5 & $44 \%$ \\
\hline & Rest and personal & 10.5 & $44 \%$ & 10.5 & $44 \%$ \\
\hline \multirow[t]{4}{*}{ Loli Pesua } & Productive work & 12 & $50 \%$ & 9 & $37.5 \%$ \\
\hline & Reproductive/domestic & 0 & 0 & 0 & $0 \%$ \\
\hline & Community/social & 3 & $13 \%$ & 6 & $25 \%$ \\
\hline & Rest and personal & 9 & $38 \%$ & 9 & $37.5 \%$ \\
\hline
\end{tabular}

The main changes for men have been as follows:

- Men's time allocation for productive work has decreased due to the loss of their livelihoods.

- There has been an increase in the amount of times pent by men on social/community activities, such as waiting for information on aid, helping with aid distributions and being involved in camp management.

- The large amount of rest time includes sleeping and non-sleeping activities (such as socializing within the campl.

- Some men lose some of their sleep time because they are required to participate in night watch duties.

- Although only to a limited extent, some men are helping with domestic work that they did not do before the emergency, e.g. gathering firewood.

\subsubsection{Women's activities}

At Kabonena camp, the daily activity cycles for women reveal a mix of productive and reproductive work, both pre- and post-disaster. For example, women who before the disaster worked selling food (nasi kuning or yellow rice) rose before dawn to cook and to do other housework such as cleaning and cooking for domestic consumption. In the afternoon, after selling their food, they took care of their children and in the evening, began preparing snacks to sell the next day. Postdisaster, women's timelines vary depending on whether or not they have managed to recover their livelihoods. Women now have to spend most of their time doing reproductive work, such as queuing to get clean water, washing clothes and dishes or bathing children. Women who have returned to selling have become the breadwinners for their families because men's livelihoods have not yet 
recovered. However, even when this is the case, responsibility for care economy work remains with women (see Table 3).

Table 3: Time use analysis for women in Kabonena camp, before and after the disaster

\begin{tabular}{|c|c|c|c|c|c|}
\hline \multicolumn{2}{|c|}{ Before the disaster } & \multicolumn{4}{|c|}{ After the disaster } \\
\hline \multirow[t]{2}{*}{ Time } & \multirow[t]{2}{*}{ Activity } & \multicolumn{2}{|c|}{ Already back to selling } & \multicolumn{2}{|c|}{ Have not returned to selling } \\
\hline & & Time & Activities & Time & Activities \\
\hline 03.00 & $\begin{array}{l}\text { Get up } \\
\text { Cook nasi kuning } \\
\text { Prepare food to sell }\end{array}$ & 04.30 & Prayer, prepare breakfast & 04.30 & $\begin{array}{l}\text { Prayer, prepare } \\
\text { breakfast }\end{array}$ \\
\hline 04.30 & Take shower & 06.00 & $\begin{array}{l}\text { Take shower, cook lunch, } \\
\text { wash clothes/dishes, } \\
\text { clean tent, take care of } \\
\text { children }\end{array}$ & 06.00 & $\begin{array}{l}\text { Take shower, cook } \\
\text { lunch, wash } \\
\text { clothes/dishes, clean } \\
\text { tent, take care of } \\
\text { children }\end{array}$ \\
\hline 04.50 & Prayer & \multirow[t]{6}{*}{09.00} & \multirow{6}{*}{$\begin{array}{l}\text { Buy materials for selling } \\
\text { rice and snacks, prepare } \\
\text { the food and rice, sell } \\
\text { rice and snacks }\end{array}$} & \multirow[t]{7}{*}{11.00} & \multirow{7}{*}{$\begin{array}{l}\text { Rest in tent, spend time } \\
\text { with neighbours, } \\
\text { particularly other } \\
\text { women survivors }\end{array}$} \\
\hline 05.00 & $\begin{array}{l}\text { Clean the house, } \\
\text { prepare breakfast and } \\
\text { food to sell }\end{array}$ & & & & \\
\hline 05.30 & $\begin{array}{l}\text { Go to sell food, open } \\
\text { market stall }\end{array}$ & & & & \\
\hline 06.30 & Sell food & & & & \\
\hline 13.00 & Rest, prayer & & & & \\
\hline 14.00 & $\begin{array}{l}\text { Take care of children, } \\
\text { prepare lunch }\end{array}$ & & & & \\
\hline 15.00 & $\begin{array}{l}\text { Go to market to buy } \\
\text { materials to sell the } \\
\text { next day }\end{array}$ & 15.00 & Return home, rest & & \\
\hline 17.00 & $\begin{array}{l}\text { Rest, afternoon } \\
\text { shower, prepare dinner }\end{array}$ & 16.00 & $\begin{array}{l}\text { Rest in tent, spend time } \\
\text { with neighbours }\end{array}$ & & \\
\hline 18.00 & $\begin{array}{l}\text { Prayer, dinner, wash } \\
\text { dishes }\end{array}$ & 17.00 & Prepare dinner, Prayer & 17.00 & $\begin{array}{l}\text { Prepare dinner, Maghrib } \\
\text { prayer }\end{array}$ \\
\hline 19.00 & $\begin{array}{l}\text { Start cooking for } \\
\text { selling the next day }\end{array}$ & 19.00 & $\begin{array}{l}\text { Dinner, take care of } \\
\text { children, clean tent }\end{array}$ & 19.00 & $\begin{array}{l}\text { Dinner, take care of } \\
\text { children, clean tent }\end{array}$ \\
\hline 22.00 & Sleep & 22.00 & Sleep & 22.00 & Sleep \\
\hline
\end{tabular}

Women in Langaleso camp were busy before the disaster with their many reproductive activities, which started at dawn, such as washing, cooking and cleaning the house. Women also bathed their children and helped them get ready for school. In the afternoon, after a lunch break and prayers, they were also occupied with preparing meals and washing clothes. Those working as farmers or farm workers went to work after finishing their housework. After finishing the farm work, they continued in the evening with domestic work such as preparing meals, cleaning the house and folding clothes. At night, food traders prepared their food to sell the next day. Women slept after finishing all their domestic work and work related to their jobs.

Women have similar work patterns after the disaster, except that they are now also involved in social work at the camp's emergency kitchen. In general, the responsibilities for reproductive work and the care economy still fall to women. At this camp, one or two women have started going back to work, which gives them more responsibility to bear. 
At Loly Pesua camp, a24-year-old woman (K.) with two children aged eight and two was interviewed. She was married at the age of 15, to a 17-year-old boy. Before the disaster, she sold fried banana while her husband worked as a stonebreaker at a factory in Loly Pesua. At the moment, $K$. is not selling fried banana as most people cannot afford to buy it; she tried once, but had no customers.

Since the disaster, women's workload has consisted largely of reproductive work and social work at the emergency kitchen. Women still carry out domestic reproductive tasks such as taking care of the children, cleaning their tents, cooking and serving their husbands. Such work now takes longer because there are queues for water and to use the toilet. Taking care of children is more difficult during the day due to lack of space in the tents and lack of ventilation, which makes them very hot. Also, if it rains, water runs into the tents and women have to move their belongings, clothes and home appliances to a safe place.

Table 4 shows women's time allocations for each category of activity, before and after the disaster.

Table 4: Summary of time use analysis for women, before and after the disaster

\begin{tabular}{|l|l|l|l|l|l|}
\hline \multirow{2}{*}{ Camp } & \multirow{2}{*}{ Activity category } & Before the disaster & \multicolumn{2}{l}{ After the disaster } \\
\cline { 3 - 6 } & & (Time (hours) & $\%$ & Time (hours) & $\%$ \\
\hline Pacuan Kuda & Productive work & 6.5 & $27 \%$ & 0 & 0 \\
\hline & Reproductive/domestic & 5 & $21 \%$ & 8.5 & $35 \%$ \\
\hline & Community/social & 0 & 0 & 3.5 & $15 \%$ \\
\hline & Rest and personal & 12.5 & $52 \%$ & 12 & $50 \%$ \\
\hline & Productive work & 13 & $33 \%$ & 6 & $25 \%$ \\
\hline & Reproductive/domestic & 6 & $46 \%$ & 6 & $25 \%$ \\
\hline & Community/social & 0 & $0 \%$ & 4 & $17 \%$ \\
\hline & Rest and personal & 5 & $21 \%$ & 8 & $33 \%$ \\
\hline & Productive work & 8 & $33 \%$ & 0 & 0 \\
\hline & Reproductive/domestic & 10 & $42 \%$ & 10 & $42 \%$ \\
\hline & Community/social & 2 & $8 \%$ & 6 & $25 \%$ \\
\hline & Rest and personal & 4 & $17 \%$ & 8 & $33 \%$ \\
\hline & Productive work & 6 & $25 \%$ & 0 & $0 \%$ \\
\hline & Reproductive/domestic & 8 & $33.5 \%$ & 10 & $42 \%$ \\
\hline & Community/social & 2 & $8 \%$ & 2 & $8 \%$ \\
\hline & Rest and personal & 8 & $33.5 \%$ & 12 & $50 \%$ \\
\hline
\end{tabular}

The main changes for women have been as follows:

- Then time allocated to productive activities has decreased sharply compared with before the disaster. The disaster has destroyed women's main sources of income.

- Some women have succeeded in overcoming these challenges, and have become the main breadwinners for their families. However, these women still have the same responsibilities for carrying out reproductive/caring roles as they did before the disaster.

\subsubsection{Activities of girls and boys (aged 8-18)}

Before the disaster, girls carried out activities such as washing dishes or sweeping the house, before taking a shower and going to school. After coming home from school, they typically took a nap and then did housework (sweeping, washing dishes and cooking rice). At night, they spent time with their peers, studying and socializing. Sometimes, girls stayed at home checking their phones or chatting with family. 
Boys' activities were different. After waking up in the morning, typically boys would shower and then go to school until noon. In the evening, they played football. At night, similar to girls, boys socialized with their male peers or stayed at home. However, boys were not involved in doing any housework.

After the disaster, there have been some changes to boys' daily activity cycles, with more free time now. After waking up, they go to school, and then after school they spend most of their time resting. Girls still do domestic work such as washing dishes and cooking, but these responsibilities are much heavier now than before the disaster as facilities are limited. Interestingly, some boys help their parents to gather firewood. There are some risks associated with this activity -being attacked by wild animals (snakes, monkeys and wild boar) for boys and girls, and sexual harassment for girls. At night, boys sometimes socialize but most of the time they stay in the family tent doing nothing.

Girls tend to contribute time to domestic tasks such as cooking, caring for younger siblings or washing clothes, and the time spent on such activities has increased as their mothers are spending time in communal kitchens. They still perform these roles despite the limitations post-disaster, such as a lack of clean water and cooking equipment. At Pacuan Kuda camp, some boys are helping with the domestic workload by collecting firewood and drawing water from a well. The boys reported that they had never participated in domestic work before the disaster. Even if their current role involves seemingly simple tasks, their participation may be a good starting point for encouraging a more equal distribution of reproductive tasks within the family. This capacity should be built upon in the response.

\subsubsection{Activities of female-headed households}

Women heads of household performed both reproductive and productive work le.g. working as market traders or on a farm) before the disaster. After the disaster, as well as social activities at emergency kitchens, women heads of household are working to earn money by salvaging items from the ruins. At the same time, they must still carry out their reproductive activities.

\subsubsection{Activities of women with disabilities}

The activities of women with disabilities are reflected in the daily cycle of W., a woman with a hearing impairment. She is 27 years old and is single. Before the disaster, she did tasks inside the house, including washing dishes, cleaning and helping to cook. She rarely performed activities outside the home. After the disaster, she is still preoccupied with domestic activities but is carrying out a wider range of activities, including cooking, washing clothes, cleaning tents, cleaning houses affected by the disaster and collecting clean water.

In addition to women with disabilities, it is important to consider the daily cycle of women who have family members with a disability, because socially the responsibility for caring and supporting persons with disabilities usually falls to women. For example, B. is the mother of an 11-year-old girl who has a visual impairment and a hearing problem. Because of these disabilities, the girl only managed to attend up to the third grade of elementary school and then had to drop out before the disaster, and she has not returned to school while living in the IDP camp. Based on B.'s statements and on direct observation, B. does many jobs (such as working at the emergency kitchen) while also taking care of her daughter (in particular ensuring that she does not bump into things). As there are quite a few children of the same age in the camp, her daughter has many friends to socialize with and this helps to reduce B.'s responsibilities to some extent.

\subsubsection{Activities of LGBTI people}

The daily cycle of activities studied was that of T., a 30-year-old transgender woman living at Dusun 3, Desa Langaleso camp in Sigi district. T. is often mocked for her sexual orientation. She tries to 
appear masculine, although she does not feel comfortable with this. She feels uncomfortable using the men's bathroom, but she tries to ignore this as she also feels that other women are uncomfortable with her using the female bathroom. Before the disaster, she worked in the rice fields most of the day, and also helped her mother with domestic tasks. Since the disaster, she has been participating in community activities, helping with the distribution of aid and also helping the women at the emergency kitchen. She hopes that these activities will help her to be accepted.

It is worth noting that the LGBTI community is very diverse and is made up of many individuals who have different capacities and vulnerabilities. Not all LGBTI people are like T., who has tried to blend in and be accepted by her community; many opt to reduce their social interactions due to low levels of acceptance and the fact that they face harassment.

\subsubsection{Main conclusions of the care analysis}

Table 5: Main conclusions of the care analysis

\begin{tabular}{|c|c|}
\hline Before the disaster & After the disaster \\
\hline $\begin{array}{l}\text { There was a distinct gendered division of labour } \\
\text { even within productive work e.g. men went to sea } \\
\text { to catch fish while women cleaned and sold the } \\
\text { fish. }\end{array}$ & $\begin{array}{l}\text { The gendered division of labour has been replicated } \\
\text { within the camps e.g. in camp management, with } \\
\text { men required only to build tents in the first place, } \\
\text { while women must clean the camp every day. }\end{array}$ \\
\hline $\begin{array}{l}\text { Women undertook both productive and } \\
\text { reproductive work, while men did generally only } \\
\text { productive work. }\end{array}$ & $\begin{array}{l}\text { Women's jobs, such as cooking food to sell, are } \\
\text { more difficult than they were before. Most women's } \\
\text { cooking equipment was lost or damaged in the } \\
\text { disaster. In addition, many of their food businesses } \\
\text { were home-based. For women who have returned to } \\
\text { work and have become the family breadwinner, } \\
\text { roles and responsibilities for reproductive/caring } \\
\text { work remain the same, which means that they now } \\
\text { have a double burden. }\end{array}$ \\
\hline $\begin{array}{l}\text { Women's workloads were weighted towards } \\
\text { domestic work, which took up most of their time } \\
\text { and energy. }\end{array}$ & $\begin{array}{l}\text { Women still do domestic work such as cooking, } \\
\text { washing clothes and childcare. However, most } \\
\text { cooking is now done collectively at emergency } \\
\text { kitchens, except for breakfast (which woman } \\
\text { prepare at home or sometimes buy). }\end{array}$ \\
\hline $\begin{array}{l}\text { Men spent most of their time on productive work } \\
\text { and on social and personal activities. }\end{array}$ & $\begin{array}{l}\text { Men are now unemployed. Most do not get involved } \\
\text { in domestic work, which remains the responsibility } \\
\text { of women. However, at Langaleso camp, some men } \\
\text { have started helping their wives to gather firewood. } \\
\text { Some boys at Pacuan Kuda camp are also collecting } \\
\text { firewood as they have more free time. }\end{array}$ \\
\hline Women's working hours tended to be longer. & $\begin{array}{l}\text { Women are expending more time and energy on } \\
\text { reproductive work after the disaster due to the time } \\
\text { spent queuing, the distance to toilet facilities and } \\
\text { the loss of their home appliances. They spend a lot } \\
\text { of time buying food and other essential items if they } \\
\text { are not receiving aid supplies. Some items, such as } \\
\text { seasonings, are not provided by aid agencies. }\end{array}$ \\
\hline $\begin{array}{l}\text { Women had less rest time: for example, during the } \\
\text { lunch break they had to feed their children or serve } \\
\text { meals for their husbands. }\end{array}$ & $\begin{array}{l}\text { Women now have free time due to being } \\
\text { unemployed. }\end{array}$ \\
\hline
\end{tabular}




\section{GENDER ISSUES IN INDIVIDUAL SECTORS}

\subsection{GENDER ISSUES IN THE WASH SECTOR}

\section{Findings relevant to all camps}

Findings from field observations and from the FGDs indicate that women have a particular interest in the availability of clean water and sanitation facilities because of their gender roles. They need clean water for bathing their children, washing their families' clothes and for their own reproductive health needs during menstruation.

Overall, there is limited clean water available. For example, water distribution in Kabonena camp is insufficient to meet daily needs. Sanitation facilities are designed only for defecation, and the affected population must find other places to bathe and to wash clothes. This is an extra time burden, especially for women. Rivers are used as an option in some camps; however, the quality of river water cannot be guaranteed, and some women pointed out that walking to the river involves protection risks. The river near Pacuan Kuda camp is used as disposal site for chemical waste by the PLTU electricity plant, and in Langaleso the river water is polluted by human faeces, as well as by mud and by corpses buried by soil liquefaction.

There is insufficient lighting in the camps, including around public toilets, which puts women and girls at risk of GBV. Toilets were reported to have adequate locks, however.

Access to clean water and sanitation facilities in the aftermath of a disaster is essential for the affected population. According to Indonesia's Ministry of Health, in an emergency the minimum standard for clean water is 15 litres per person per day (in line with the Sphere Minimum Standards), and the water source should be located no further than 500 metres from the settlement. There should be at least one toilet for every 80-100 people, with a queuing time of no more than 15 minutes. ${ }^{23}$ However, these standards are not being met in many of the camps.

For LGBTI people, WASH facilities are a major source of complaint. As toilets are separated into two sexes (male and female), LGBTI people sometimes have difficulty in accessing them. They are often rejected by other users and have experienced verbal abuse. For example, T., a 30-year-old transgender woman, reported feeling uncomfortable when attempting to use both the men's and the women's toilets.

Young women said that they need more clean water to be able to manage their periods, and they also have a need for underwear.

\section{Findings from specific camps}

Despite there being two water sources, the water from the pump in Pacuan Kuda camp is dirty and cloudy. This camp has 10 toilets located in two different areas, six for women and four for men, and there is adequate lighting. However, women rarely use the facilities since they frequently run out of water, and there are only a few rainwater collection tanks provided by the camp management. Therefore women (and some men) prefer to bathe, defecate and wash their clothes in the river, even though it is around $1 \mathrm{~km}$ from the camp. Men reported requiring less water than women and they were less averse to using the public toilets for defecation. 
In Kobanena camp, sanitation facilities were found at two shelters, on either side of the main road. Clean water is accessed from water barrels located around the shelters. The affected population, especially women, were also using the sanitation facilities of relatives and neighbours for bathing and washing clothes. According to An (female, 60 years old), the clean water supply is sufficient only for cooking and going to the toilet, and people have been banned from using the water for bathing or washing clothes.

Langaleso military command centre (a military barracks that is now being used as a camp) has seven toilet facilities that were built before the disaster. These were funded by the National Programme for Community Empowerment(PNPM) and were managed by men. However, the facilities were damaged in the disaster, and men and women now prefer to defecate in the river, shielding themselves with a sarong for privacy. The same river water, which is muddy and contaminated with chemical waste, is used by the affected population for bathing, and cases of diarrhoea and itchy skin have been reported. Although clean water is supplied by volunteers, the affected population prefer to use water from the pump for drinking as it is perceived to taste better, even though it may not be clean. The camp management confirmed that officials are planning to build toilets in five more areas.

In Loli Pesua camp, clean water is provided by a state-owned company, Perusahaan Daerah Air Minum (PDAM), which is located nearby. Two toilet units segregated by sex are also located near the shelters. Every family contributes to keeping the shelters clean and tidy. There are water barrels in many areas of the camp, where women gather in the morning and at midday to carry out domestic work. However, there is minimal lighting around the shelters and the WASH facilities. Only one light was noted at the public toilet, and there was no lighting on the road between the toilet and the shelters.

\subsection{GENDER ISSUES IN THE LIVELIHOODS SECTOR}

\section{Findings relevant to all camps}

Most men and women are still unemployed. Most male labourers are doing unskilled work paid on a daily basis such as low-skilled construction work or collecting fares on the minibus-style shared taxis used for public transport (angkutan kota), while waiting to hear from their former employers. Some construction labourers have returned to work as there is a need to rebuild after the disaster.

Many women have lost their livelihoods, which were often home-based, such as making and selling food or running grocery shops, beauty salons or small tailoring businesses in their houses. When their homes were destroyed or damaged, they also lost their livelihoods. Other women used to sell fish, but the demand for fish has fallen: most people in Palu are fearful of eating it, as they fear that the fish have eaten the bodies of those lost in the disaster.

Fishermen have lost their assets as a result of the disaster. Even before the disaster struck, many fishermen were experiencing difficulties because of a mining project by a big company on the coast at Langaleso that led to fish becoming smaller in size, as well as a reduction in the size of their catch. There was a similar problem at Tawaeli, another area affected by the earthquake, where a PLTU project affected fishery resources.

Many of the affected population are suffering from post-disaster trauma lalthough this has not officially been diagnosed as PTSD), which has affected their capacity to work.

Women are generally seen by society as secondary providers of livelihoods within the household, even when they are earning more than men. This assumption affects their bargaining power both in the family and in public - for example, some women's jobs, such as selling fish, are not seen as a valued part of the fisheries industry. 


\section{Box 1: Gender-based privileges after the disaster}

Women and men have both faced sharp falls in income, the destruction of their homes and post-disaster trauma, but the impacts on livelihoods may be different due to differences between men and women in terms of access to and control over resources.

The analysis found that, in terms of making decisions on how to spend income, men tend to have certain privileges. After the disaster, some men are still smoking as many cigarettes as they did before, even if they are unemployed, though the focus groups suggest that half of them have reduced the amount they smoke to save money. In order to buy a packet of cigarettes, they collect and sell scrap metal that can be reused for roofing.

Decision-making patterns vary from household to household. Some households said that men and women make decisions together, while some said that women generally manage everything to do with daily consumption but that when it comes to bigger expenses, such as buying assets, men usually have more of a say over decisions.

According to Y. and H., two transgender women from Palu city, before the disaster most LGBTI people worked in the informal sector, many of them in beauty salons and the rest as sex workers, or 'night workers'. Those working in beauty salons suffered a sharp loss of income as the disaster damaged buildings, equipment and basic infrastructure such as the clean water supply, which is vital for such businesses. In addition, people's purchasing power has been reduced since the disaster and this has also affected business.

Female-headed households face particular challenges in restoring their livelihoods. Despite the challenges, many women have restarted their businesses selling vegetables, beverages or snacks (such as cassava or banana chips). Some women rely on community resources such as relatives who have not been affected by the disaster as asocial safety net; relatives have provided food and cooking and other domestic equipment. Some women have taken out high-interest loans from local (non-bank) financial institutions. Others, in order to overcome their lack of equipment, have been searching for usable equipment amongst the ruins.

\section{Box 2: How female-headed households are coping - four case studies}

Yan (27 years old) is an unmarried woman who became head of her household after losing her parents and grandmother in the disaster. She has been left looking after her younger brother and sister. A month before the disaster, Yan accepted a job at a local hotel, with a salary of IDR 800,000 (US\$56) per month. She is using this salary to support herself and her younger siblings.

Y. (70) currently lives in Langaleso with her daughter, son-in-law and three grandchildren. Her husband has left her. Before the disaster, Y. sold fruits and vegetables at Masomba market, and also grew produce to sell there. To reach Masomba, she had to spend IDR 25,000 (US\$1.75) each day on public transport. She spent some of her earnings on buying food and saved the rest to build a small shop right in front of her house. She worked hard to make ends meet for all her family members. However, the disaster flattened her house, leaving nothing but the small shop, which was looted. She got a loan (IDR 300,000/ US\$21) from a relative and is now trying to rebuild her livelihood by selling fruits and vegetables close to her house. 
Sy (50) has been a widow for five years, and lives near Loli Pesua command centre. Two weeks after the disaster, she started a small business, setting up a stall at the side of the main road connecting Palu to Donggala. To get started, she obtained a loan of IDR 500,000 (US\$35) from a credit union (koperas). Due to the limited options available, this was a high-interest loan and she has to repay it in instalments of up to IDR 75,000 (US\$5) every month.

In Kabonena camp, K. has begun to rebuild her livelihood by selling beverages and snacks to other survivors. Her profit from this small business is around IDR200,000-300,000 (\$US14-21) per day, but before the disaster her daily profit from her food business was IDR 700,000800,000 ( $\$$ US49-56). She has now become the primary earner in her family.

\section{Findings from specific camps}

Most women in Pacuan Kuda camp have lost their livelihoods, which for many involved selling fish. The disaster resulted in the loss of many men's boats and fishing equipment. Most women now depend on money earned by their husbands from unskilled work, such as low-wage construction work, scavenging scrap materials from damaged buildings and some limited cash-for-work programmes. Some children also collect scrap materials to sell.

In Kabonena, most of the affected population were vendors or construction workers before the disaster, and they have not yet returned to work. According to Sub (female, 45, fish vendor), since the disaster there has been a lack of buyers and the fish market is deserted. She said, 'People are still afraid to eat fish because they think it has been contaminated by human corpses. I am afraid I will lose all my investment if I start selling fish. 'Two other women, As, who sold fabrics, and Id, who sold food in a school cafeteria, have experienced a similar loss of income. Id lost all her capital because of the disaster. She commented, 'I can't start my business again because I've lost my pans and all my cooking equipment is broken. I can't make nasi kuning anymore.' Currently Id is selling cold drinks in IDP camps and earning around IDR 300,000 (\$US 21) per day. She said that she had an income of up to IDR 800,000 (US\$56) per day prior to the disaster. Ren (male, 75) was a construction supervisor but since the disaster no one has hired him. Tand (male, 47) faces a similar problem, having lost his job after his office halted a construction project because of the disaster.

In Langaleso camp, most men were previously farmers, while women were farm labourers and vendors. Women earned around IDR 50,000 (about \$4) per day and men earned IDR 60,000 (\$5) for similar tasks. Following the disaster, most men are now collecting and selling building materials that have some value, like zinc sheeting, and use the money to buy cigarettes lother needs are currently covered by aid distributions). Most women are selling cakes, either traditional or modern. They save their earnings or sometimes use them to buy cigarettes for their husbands. Langaleso is known as a migrant worker village. Between2000 and 2018, some 350 women left the village to become migrant workers on fixed-term contracts in a number of different Asian countries, including Brunei Darussalam, Hong Kong, Saudi Arabia, Malaysia and Singapore. One woman interviewed was undecided as to whether or not she would return to work as a migrant, as she was worried about the well-being of her husband and son. Most female migrant workers were also worried that their husbands might be having affairs in their absence. It is not clear whether these concerns have changed since the disaster. The number of migrant workers with weak legal protection might grow post-disaster due to increased levels of vulnerability, including the loss of livelihoods and an increase in the prevalence of domestic violence (physical, mental and sexual).

In Loli Pesua camp half of the population, both male and female, were working as labourers at a stone crushing plant nearby. The rest were still unemployed, due to a lack of capital and business equipment. 


\subsection{GENDER ISSUES IN THE SHELTER SECTOR}

\section{Findings relevant to all camps}

The main finding relates to the lack of privacy in shelters. Many tents lack partitions to separate one family from another. They also lack adequate lighting, and are perceived as unsafe. These conditions increase the risk of GBV for women and girls, a fear expressed by some in the FGDs and interviews.

The fluctuating temperatures inside shelters (hot by day, cold by night) are a particular issue for infants, children and older people, who spend more time indoors.

\section{Findings from specific camps}

In Pacuan Kuda camp, shelters consist of large tents set up on a football field. There are 2-3 families in each tent, with no partitions to separate one family from another. The command centre has a public kitchen, a prayer room and a public area. Twelve temporary shelter blocks were under construction at the time of the assessment, while lighting facilities were provided for free by stateowned company PLN. At the time of the assessment, the affected population was playing no active part in shelter construction.

Kobanena camp also consists of tents in a field. There are 1-2 families in each tent, with no partitions. There are also a public tent, a healthcare tent and a public kitchen.

Conditions are different in Langaleso camp, with tents and other shelters dispersed across many different areas. There are 120 heads of household in Langaleso. Half of them have chosen to live in temporary houses made of wood that they have built themselves, using salvaged materials from damaged houses. However, some of these are built on rice fields and when it rains the ground becomes waterlogged and the temperature drops, and people complain of being cold. The tents in the camp are not a pleasant environment for pregnant women, breastfeeding mothers or people with disabilities, especially when they are wet. Women and girls are responsible for cleaning the shelters.

At the time of the assessment, the affected populations from Loli Pesua and Loli Saluran were still living in tents. In Loli Pesua, each family has its own tent. Nevertheless, some tents do not have adequate lighting.

\subsection{GENDER ISSUES IN THE FOOD SECURITY SECTOR}

\section{Findings relevant to all camps}

Most of the affected population have been reliant on food aid and therefore would have been at risk of food insecurity when aid distributions stopped for men, women, boys and girls. However, the situation has now improved (as of June 2019) and, although some community members without resources are still reliant on aid, most are resuming their daily livelihoods activities.

The gendered aspects of food security are important to consider. Women play a key role in providing food for their families, and food insecurity has an impact on the time burden that women face as well as increasing stresses around the daily financial management of the household. In some camps firewood for cooking is collected by both men and women (e.g. Langalesol, and in other camps boys also collect firewood in addition to girls (e.g. Pacuan Kuda). 


\section{Findings from specific camps}

In Pacuan Kuda, women usually go directly to the main tent for their daily food needs; the tent is in an accessible location. Sometimes women have to buy necessities outside the camp. They also have to save money in order to buy clean water for cooking and drinking, but no information was available on how (or whether) they manage to do that. Shelters have limited cooking equipment, as families' own equipment was lost or damaged in the disaster.

In Kabonena and Loli Pesua, the affected population also depend on aid distributions for their daily needs, with each family receiving rice and other culinary necessities. The Parigi Moutong administration provides nasi bungkus (rice wrapped in banana leaves) in the public kitchen in Kabonena.

People in Langaleso were cut off by damage to the road, with access possible only by motorbike. Access to motorbikes was the same for men and women, except for older people, when men had more access. The damage to rice fields and farms may result in a failed harvest, leading to further insecurity and increases in the price of food.

Data were not collected during this research on the preferred modality of food aid le.g. cash, cash for work, direct food distribution). It is recommended that future research should confirm which modality would be most empowering for women.

\subsection{GENDER ISSUES IN THE EDUCATION SECTOR}

\section{Findings relevant to all camps}

Many school buildings were damaged in the disaster. In some places, temporary schools have been set up in tents by local government, humanitarian organizations and volunteers. However, many children complain about high daytime temperatures in tents, and most children and their parents have been severely traumatized by the disaster and children are still too afraid to return to school.

Many teachers were themselves victims of the disaster. Their responsibilities have increased as they are now helping their students to cope with post-disaster trauma Ithough not officially diagnosed as PTSD). Psychosocial support needs to be provided for school children and teachers, and teachers need training on how to provide this support to students. Currently many schools have no psychosocial element in the curriculum or activities that could help children cope with the trauma of the disaster and its aftermath. However, some other organizations are providing these services in the camps.

Teachers lack disaster preparedness knowledge in general. Most primary school teachers are women. In this research, interviews were not carried out with women teachers due to time constraints, but this could be considered in further research in order to understand their specific practical and strategic needs.

\section{Findings from specific camps}

In Pacuan Kuda, two primary schools were hit by the tsunami. Temporary school classes are being held in a tent, and uniforms and school kits have been provided by volunteers. However, as most of the teachers were themselves affected, classes have not yet restarted effectively.

In Langaleso, a school building was damaged structurally by the earthquake and then filled with mud and floodwater after liquefaction altered the course of a river. Langaleso also has a temporary school set up in a tent near the settlement. 
In Kabonena, students have begun to return to school and have started classes in a tent provided by the school principal. Children are studying for four hours a day, using makeshift school kits received from volunteers. Teachers are offering psychosocial support for children with the help of volunteers. In Loly Pesua, students are also starting to return to school.

\subsection{GENDER ISSUES IN THE HEALTH SECTOR}

\section{Findings relevant to all camps}

In general, health services are focused on meeting basic needs. Reproductive health services were found in only a few camps. The lack of reproductive health services increases the risks of unwanted pregnancy and sexually transmitted diseases and more generally affects well-being, especially for women.

\section{Findings from specific camps}

In Pacuan Kuda, a doctor, a midwife and health workers provide a regular basic health service (around 2-3 times a week). According to affected women, reproductive health information is not provided. At the time of the assessment, two women reported being pregnant. Residents in Pacuan Kuda were exposed to chemical waste from the PLTU electricity plant before the disaster. They suspect that the waste causes leukaemia, and some of them have reported deaths. Women are more exposed to the chemicals, since they do the family's washing in the river. Their cleaning work also makes them more vulnerable to dust contaminated by chemical waste.

In Kabonena, two health centres have been built near the shelters, while in Langaleso health services are being provided by Poskesdes (a village health centre) located around $1 \mathrm{~km}$ from the command centre. The Poskesdes clinic is in good condition and is well stocked with medicines, and the midwife is in attendance from 8am to2pm. The clinic has a particular focus on maternal and neonatal healthcare, and regular health sessions are held for pregnant women and children aged under five. This service is free for holders of the Kartu Indonesia Sehat (KIS) card, which entitles users to free health services. The affected population in Langaleso are also receiving free health services from volunteers, including family planning services. In Langaleso camp, an integrated health service post (Posyandu) opened a month after the disaster. Health volunteers at the post, who have received training from the local health office, provide health guidance for pregnant women and nursing mothers. The Posyandu facility was mobilized by women and is a resource that can be built on. In Loli Pesua, health services are being provided by the Indonesian Red Cross (PMI).

\subsection{GENDER ISSUES IN THE PROTECTION SECTOR}

In a post-disaster situation, protection is about improving safety in order to ensure that people are free from violence and coercion and that they receive the assistance they need. Protection looked at through a gender lens involves examining how these risks affect men, women, girls and boys and particularly looks at risks of GBV and sexual abuse and exploitation. At the time the research was undertaken, no complaints mechanisms had been established.

\section{Gender-based violence}

\section{Issues relevant to all camps}

Women have limited information about what to do if they are the victim of or a witness to GBV. There is limited information about women's rights, legal protections and the availability of paralegal services, which represents a protection risk for the affected population. There are some 
organizations that provide such services (e.g. LBH APIK and LBH Central Sulawesi), but they do not cover all the camps.

Girls expressed concerns about falling victim to GBV because of the lack of lighting in some areas in the camps, such as on roads connecting shelters and toilet facilities.

Child marriage, which was an issue before the emergency, puts girls at a greater risk of GBV. In Loly Pesua camp, researchers talked to one young couple who had been married a month before the disaster. The bride was a 16-year-old girl who had chosen to marry in order to escape violence from her own father. She had also left school. Although there are no data available on child marriage after the disaster, the increased vulnerabilities that families are facing increase the likelihood of them resorting to child marriage. Economic factors are the main reason for this: reduced incomes post-disaster can mean that people turn to child marriage in order to reduce their financial burden.

Some cases of rape of young people have been reported. For example, a child was raped in Makassar, the capital of South Sulawesi, after her family fled there from Central Sulawesi in search of safety just after the disaster. ${ }^{24}$

LGBTI people have been subject to harassment since the disaster, both in person and on social media. Some people hold cultural and religious beliefs that the earthquake was a punishment by God for people's sin, and some have accused LGBTI people of being the cause of the disaster. These accusations have been accompanied by pressure to 'repent'; for example, in Langaleso camp youths from a religious group put pressure of this kind on $15 \mathrm{LGBTI}$ people living there.

\section{Issues in specific camps}

In Loli Pesua, a few days before the assessment was carried out, a woman had experienced physical violence from her husband in an argument over their children's behaviour. The victim has since moved in with her parents.

Women in Pacuan Kuda expressed concerns that they were likely to experience abuse and harassment from labourers working on a site where temporary housing is being built. They feel unsafe walking outside and around the camp alone at night, and fear being harassed in the street. Girls also worry about sexual abuse while bathing at the river, which they do due to the lack of toilet facilities in the camps. They feel particularly unsafe accessing the river at night. They often ask a family member to accompany them to the latrines or to the river as a protection mechanism, although this in itself makes them feel uncomfortable.

\section{Disaster risks}

There is a lack of information about disaster risks in the area and therefore a lack of preparedness and knowledge about self-rescue. Women are more at risk as they have less access to information. Also, few women have self-rescue kits, which were distributed by humanitarian organizations after the disaster; these contain a whistle and a flashlight, food, hygiene items and toiletries.

The mining project at Loli Pesua increases the risk of another disaster as it has cut intothe mountainsides, making them prone to landslides. According to a study conducted by LBH APIK and given to the Ombudsman in 2017 (private communication), mining activities risk causing landslides in the hills above the Loli Pesua camp, representing a threat for the whole population.

\section{Legal documents}

Most fishermen were working without legal documents or insurance even before the disaster, and many documents that have been issued are valid only for one year. The Indonesian government issues a card specifically for fishermen that can be used to access insurance benefits or credit with a financial institution. Some fishermen have identification cards, but often a different occupation is stated on their cards, so they are not eligible for those benefits. The process of applying for a card is time-consuming. Women are normally considered to be supporting their spouses, so they are not 


\subsection{GENDER ISSUES IN THE CAMP MANAGEMENT SECTOR}

Women's participation and influence in camp management can be a strategic factor in a postdisaster situation. Their participation can encourage equality in resource management and help to ensure that women and men benefit equally from aid resources.

\section{Findings relevant to all camps}

There is limited participation by women in camp management. Where women do not participate in camp management (i.e. in the command centre), they tend not to be involved in decision making. Although camp management is dominated by men, a few women have taken on leadership roles in the emergency response.

\section{Box 3: Case study - a woman takes the lead}

Sus, aged 42 , is the leader of the Pacuan Kuda camp. She is an alumnus of Palu University and a mother of two children. On 28 September 2018 she lost her husband, along with her house and all her belongings. With her children and seven neighbours, Sus escaped to the mountains, and after three weeks returned to find a place to build a camp. She chose a field in Pacuan Kuda as it was the nearest place to a water source. She moved into the camp with another 11 households, and took on the role of camp leader to manage it better. She met formally with the sub-district leader, advocating with the government for aid for the camp. The first aid that arrived was from the military, which provided 50 tents and helped with other logistical needs. Temporary schools were set up by the local education agency, followed by a clean water supply, electricity and toilets. At that point, Pacuan Kuda was properly established as a temporary place of shelter.

There is some participation by women in the management of public kitchens, though this varies significantly between camps. Some kitchens are managed by the affected population and others by the host community. Where women are working in a public kitchen, they report that it has become an important social space where they can share their feelings, relieve stress and feel more positive. In Loly Pesua and Kabonena camps, however, only a few women are involved in public kitchen management.

LGBTI people also rarely participate in decision making. However, they often join LGBTI groups, which could be a resource to build on.

\section{Findings from specific camps}

In Pacuan Kuda camp, which has a woman as camp leader, women and men tend to be involved equally in the management of aid. However, according to men, their personal necessities have not always been taken into account, such as the provision of razors and prayer caps.

In Loly Pesua, a woman is also participating in camp management. Unfortunately, she was not available during the data collection process, and no further information was available about her contribution. Women also lead the management of the public kitchen; however, the cooks are local residents rather than members of the affected population. Only one or two women from the camp are actively involved in kitchen management. 
Meanwhile in Kabonena, management of the camp is dominated by men, with only one woman participating as a helper. Men dominate decision-making processes, while women tend to be passive participants. Furthermore, basic needs distributions in Kabonena are managed by group leaders who are all men. Women are less involved and more passive because they are perceived as being weak victims - by men, by group leaders and sometimes by women themselves. The participation of women in community meetings should be actively encouraged; in an FGD they identified this as a strategic need but felt unable to express their need to men.

In Langaleso, men manage and coordinate the camp, and the leader is a 'gatekeeper' for distributions. Even though women contribute fully in managing the public kitchen, they are not involved in decision making and do not have access to or control over aid distribution. However, according to women, aid items are distributed evenly between women and men. 


\section{CONCLUSIONS AND RECOMMENDATIONS}

The key findings are presented below, together with recommendations aimed at the main actors involved in the response.

\begin{tabular}{|c|c|c|c|}
\hline & Key findings & Actor & Recommendations \\
\hline \multirow[t]{9}{*}{$\begin{array}{l}\text { All sectors/ } \\
\text { general } \\
\text { recommendations }\end{array}$} & \multirow{2}{*}{$\begin{array}{l}\text { Women in particular are } \\
\text { facing an increased time } \\
\text { burden as a result of having } \\
\text { to spend more time on } \\
\text { WASH activities. This has } \\
\text { exacerbated pre-existing } \\
\text { inequalities in the division } \\
\text { of labour, as women } \\
\text { already spent more time } \\
\text { than men on activities such } \\
\text { as washing, cleaning and } \\
\text { bathing children. In } \\
\text { particular, the increased } \\
\text { time required to access } \\
\text { water has widened this } \\
\text { inequality. }\end{array}$} & $\begin{array}{l}\text { Government, } \\
\text { UN and } \\
\text { NGOs/CSOs }\end{array}$ & $\begin{array}{l}\text { WASH sector NGOs should prioritize interventions } \\
\text { that reduce the time that people need to spend } \\
\text { on these activities. } \\
\text { All other sectors should ensure that activities do } \\
\text { not create an additional time burden for women } \\
\text { and that they are designed to enable women's } \\
\text { participation, e.g. by offering childcare options. }\end{array}$ \\
\hline & & Donors & $\begin{array}{l}\text { Donors should ensure that funding is allocated } \\
\text { and is flexible enough to enable women to } \\
\text { participate in economic activities e.g. by } \\
\text { providing childcare facilities. Women could also } \\
\text { be paid to provide childcare services } \\
\text { themselves. }\end{array}$ \\
\hline & \multirow{4}{*}{$\begin{array}{l}\text { Few official SADDD are } \\
\text { available. Such data are } \\
\text { essential not only for } \\
\text { understanding } \\
\text { humanitarian needs but } \\
\text { also for showing that there } \\
\text { is a rights-based approach } \\
\text { where all individuals are } \\
\text { respected. Crises affect } \\
\text { women, men, boys and girls } \\
\text { and people living with } \\
\text { disabilities in different } \\
\text { ways. SADD as part of the } \\
\text { broader gender analysis } \\
\text { allow humanitarian actors } \\
\text { to understand the situation } \\
\text { and adapt programmes to } \\
\text { meet the needs of } \\
\text { individuals affected by the } \\
\text { disaster. This results in } \\
\text { more effective } \\
\text { programming. }\end{array}$} & Government & $\begin{array}{l}\text { Official data should always be disaggregated by } \\
\text { sex, age and disability. This will enable all actors } \\
\text { to use government data to plan a more effective } \\
\text { response that meets the needs of all women, } \\
\text { men, boys and girls. }\end{array}$ \\
\hline & & UN & $\begin{array}{l}\text { UN agencies should work with the national } \\
\text { government to ensure the collection of SADDD as } \\
\text { quickly as possible }\end{array}$ \\
\hline & & Donors & $\begin{array}{l}\text { Donors should insist on the use of SADDD for the } \\
\text { design of any programmes that they fund, and } \\
\text { should budget for the collection of SADDD } \\
\text { throughout the response. }\end{array}$ \\
\hline & & $\mathrm{NGOs/CSOs}$ & $\begin{array}{l}\text { NGOs should use all SADDD available and should } \\
\text { collect their own data where possible. Where } \\
\text { official SADDD are not available, NGOs should } \\
\text { derive estimates statistically, based on data } \\
\text { available (for examples, see IASC (2017). The } \\
\text { Gender Handbook for Humanitarian Action). }\end{array}$ \\
\hline & \multirow{3}{*}{$\begin{array}{l}\text { There was a high rate of } \\
\text { child marriage before the } \\
\text { emergency. More research } \\
\text { is needed to find whether } \\
\text { families are resorting more } \\
\text { frequently to this common } \\
\text { cultural practice as a } \\
\text { negative coping strategy. }\end{array}$} & Government & $\begin{array}{l}\text { The government should collect data on the } \\
\text { incidence of child marriage to ensure that it is } \\
\text { not being used as a negative coping strategy. } \\
\text { Economic opportunities should be targeted } \\
\text { towards very poor families. }\end{array}$ \\
\hline & & UN & $\begin{array}{l}\text { UNICEF and other UN agencies should include } \\
\text { child marriage prevention strategies in their } \\
\text { programming, such as awareness raising on the } \\
\text { impacts of child marriage. }\end{array}$ \\
\hline & & $\mathrm{NGOs/CSOs}$ & $\begin{array}{l}\text { NGOs, especially those that are child-focused, } \\
\text { should include the prevention of child marriage } \\
\text { in their response programmes and should }\end{array}$ \\
\hline
\end{tabular}




\begin{tabular}{|c|c|c|c|}
\hline & & & $\begin{array}{l}\text { advocate for economic opportunities for the } \\
\text { poorest families. }\end{array}$ \\
\hline & \multirow[t]{3}{*}{$\begin{array}{l}\text { Pre-emergency data } \\
\text { indicate increasing } \\
\text { numbers of people with } \\
\text { disabilities. }{ }^{25} \text { Further } \\
\text { research is needed to see if } \\
\text { numbers have increased } \\
\text { post-disaster. This is linked } \\
\text { to the need for the } \\
\text { collection of SADDD. }\end{array}$} & Government & $\begin{array}{l}\text { Efforts should be made to obtain more accurate } \\
\text { data on the number of men, women, boys and } \\
\text { girls with disabilities after the disaster to ensure } \\
\text { that all response activities are adapted to their } \\
\text { needs e.g. WASH facilities are fitted with } \\
\text { appropriate supports for specific disabilities } \\
\text { found in each camp and in the host community. } \\
\text { People with disabilities should participate in the } \\
\text { design and implementation of the response in } \\
\text { order to ensure that their needs are met. }\end{array}$ \\
\hline & & UN & $\begin{array}{l}\text { The UN should support the collection of data on } \\
\text { people with disabilities post-disaster } \\
\text { (disaggregated by sex and age). }\end{array}$ \\
\hline & & NGOs/CSOs & $\begin{array}{l}\text { NGOs working with people with disabilities } \\
\text { should share any data they have with all sectors } \\
\text { so that all areas of the response can adapt to } \\
\text { the needs of disabled people. }\end{array}$ \\
\hline & \multirow{3}{*}{$\begin{array}{l}\text { The gender gap (as } \\
\text { measured by UNDP's Gender } \\
\text { Development Index (GDI)) } \\
\text { was already worsening } \\
\text { before the disaster. It has } \\
\text { most probably worsened } \\
\text { still further as a result of } \\
\text { the disaster, although } \\
\text { further research is needed } \\
\text { to verify this. A } \\
\text { transformative approach } \\
\text { would look to change pre- } \\
\text { existing power dynamics } \\
\text { and structural inequalities, } \\
\text { with the aim of achieving } \\
\text { long-term and sustainable } \\
\text { change. }\end{array}$} & Government & $\begin{array}{l}\text { The government should consider scaling up the } \\
\text { response and should have a clear strategy for } \\
\text { recovery that includes poverty reduction. } \\
\text { Specific targeting should be considered to } \\
\text { increase women's empowerment to, at a } \\
\text { minimum, avoid increasing the gender gap. }\end{array}$ \\
\hline & & Donors & $\begin{array}{l}\text { Donors should insist that proposals include a } \\
\text { clear long-term recovery plan that aims to be } \\
\text { transformative by changing pre-existing gender } \\
\text { inequalities. }\end{array}$ \\
\hline & & NGOs/CSOs & $\begin{array}{l}\text { NGOs must have clear sustainability strategies } \\
\text { which ensure that their responses contribute to } \\
\text { reducing gender inequality in the long term, and } \\
\text { at a minimum do no harm. }\end{array}$ \\
\hline & $\begin{array}{l}\text { Communities have little } \\
\text { information on disaster risk } \\
\text { and preparedness, and } \\
\text { women's knowledge is } \\
\text { more limited than that of } \\
\text { men. Teenagers and } \\
\text { children also have little } \\
\text { knowledge. Older people in } \\
\text { the community have some } \\
\text { knowledge from past } \\
\text { disasters. }\end{array}$ & $\begin{array}{l}\text { Government, } \\
\text { UN, donors } \\
\text { and } \\
\text { NGOs/CSOs }\end{array}$ & $\begin{array}{l}\text { Government agencies and all actors involved in } \\
\text { longer-term recovery in Central Sulawesi need to } \\
\text { invest in DRR, drawing on the lessons learned } \\
\text { from the current situation. They need to learn } \\
\text { how to operationalize measures at the } \\
\text { household level, focusing on women and young } \\
\text { people and harnessing the knowledge of older } \\
\text { men and women. }\end{array}$ \\
\hline WASH & $\begin{array}{l}\text { Although adequate drinking } \\
\text { water is available in IDP } \\
\text { camps, the quantity of } \\
\text { clean water available does } \\
\text { not meet all the needs of } \\
\text { the population, who are } \\
\text { having to turn to unsafe } \\
\text { water sources such as } \\
\text { rivers for bathing, washing } \\
\text { clothes and defecation. } \\
\text { Alternative water sources } \\
\text { do not meet standards for }\end{array}$ & $\begin{array}{l}\text { Government, } \\
\text { UN, donors, } \\
\text { NGOs/CSOs }\end{array}$ & $\begin{array}{l}\text { This practical need must be addressed urgently } \\
\text { in the response by all WASH actors in order to } \\
\text { meet the Sphere Minimum Standards. According } \\
\text { to Indonesia's Ministry of Health (in line with } \\
\text { Sphere), the minimum standard for clean water } \\
\text { needs in an emergency is } 15 \text { litres per person } \\
\text { per day, and WASH facilities should be located a } \\
\text { maximum of } 500 \text { metres from the settlement. } \\
\text { There should be at least one toilet for a } \\
\text { maximum of } 80-100 \text { people, with queuing time } \\
\text { no longer than } 15 \text { minutes. }{ }^{26}\end{array}$ \\
\hline
\end{tabular}




\begin{tabular}{|c|c|c|c|}
\hline & $\begin{array}{l}\text { distances between } \\
\text { settlements and WASH } \\
\text { facilities, and this } \\
\text { increases the time burden, } \\
\text { especially for women. }\end{array}$ & & $\begin{array}{l}\text { All those involved in the WASH sector need to } \\
\text { ensure that they play an active role and are } \\
\text { accountable for ensuring that standards are } \\
\text { met. }\end{array}$ \\
\hline & $\begin{array}{l}\text { Related to the lack of } \\
\text { adequate water supply, } \\
\text { protection (in particular } \\
\text { GBV) and health risks mean } \\
\text { that people are using } \\
\text { unsafe sources such as } \\
\text { rivers. Prevention and } \\
\text { mitigation of GBV are the } \\
\text { responsibility of all actors } \\
\text { in a humanitarian response. } \\
\text { All actors should refer to }\end{array}$ & Government & $\begin{array}{l}\text { This issue needs to be addressed by ensuring } \\
\text { that facilities in camps are adequate for all } \\
\text { needs relating to WASH (drinking, washing } \\
\text { clothes, bathing), so that people do not have to } \\
\text { resort to using rivers or neighbours' facilities. } \\
\text { The Ministry of Health needs to ensure that it is } \\
\text { monitoring for and treating water-borne } \\
\text { diseases. The Ministry of Women's } \\
\text { Empowerment and Child Protection should } \\
\text { ensure that women and girls are not at risk of } \\
\text { GBV when accessing water sources. }\end{array}$ \\
\hline & $\begin{array}{l}\text { the IASC Guidelines for } \\
\text { Integrating Gender-Based } \\
\text { Violence Interventions in } \\
\text { Humanitarian Action (2015) } \\
\text { for more information on } \\
\text { how to do this effectively. }\end{array}$ & $\begin{array}{l}\text { UN, donors, } \\
\text { NGOs/CSOs }\end{array}$ & $\begin{array}{l}\text { The WASH sector should advocate for clean } \\
\text { water supplies as soon as possible to avoid the } \\
\text { risks involved in accessing alternative sources. } \\
\text { The sector needs to be accountable for ensuring } \\
\text { that WASH facilities meet the practical needs of } \\
\text { the affected population and also meet } \\
\text { protection standards. }\end{array}$ \\
\hline & $\begin{array}{l}\text { There are protection risks } \\
\text { (GBV) due to inadequate } \\
\text { lighting at some WASH } \\
\text { facilities. }\end{array}$ & Government & $\begin{array}{l}\text { The government should ensure adequate } \\
\text { lighting and privacy at all WASH facilities and } \\
\text { should complement lighting with increased } \\
\text { security patrols, appropriate design parameters } \\
\text { and reporting mechanisms for incidents of GBV. }\end{array}$ \\
\hline & & UN & $\begin{array}{l}\text { Responsibility for the monitoring and evaluation } \\
\text { (MSE), funding and maintenance of lighting at } \\
\text { WASH facilities should be agreed at WASH } \\
\text { cluster meetings. }\end{array}$ \\
\hline & & Donors & $\begin{array}{l}\text { Ensure that budgets include adequate funds for } \\
\text { lighting WASH facilities. }\end{array}$ \\
\hline & & NGOs/CSOs & $\begin{array}{l}\text { Consider testing the effects of improved lighting } \\
\text { with a study to gauge changes in perception of } \\
\text { safety before and after lighting is installed. }{ }^{27}\end{array}$ \\
\hline Food security & $\begin{array}{l}\text { There is a risk of food } \\
\text { insecurity for men, women, } \\
\text { boys and girls when food }\end{array}$ & Government & $\begin{array}{l}\text { The government must reconsider the ending of } \\
\text { food aid if no alternatives are in place to ensure } \\
\text { that basic needs are being met. }\end{array}$ \\
\hline & $\begin{array}{l}\text { aid ends. With increased } \\
\text { food insecurity, the } \\
\text { affected population may } \\
\text { turn to negative coping } \\
\text { strategies (such as taking } \\
\text { out high-interest loans and } \\
\text { resorting to child marriage), } \\
\text { which usually affect } \\
\text { women and children more. } \\
\text { More research is needed to } \\
\text { identify what coping } \\
\text { strategies have been } \\
\text { adopted in this context. }\end{array}$ & $\begin{array}{l}\text { UN, donors } \\
\text { and } \\
\text { NGOS/CSOs }\end{array}$ & $\begin{array}{l}\text { The UN, donors and NGOs must work with the } \\
\text { government to ensure that a comprehensive } \\
\text { food security strategy is in place to make sure } \\
\text { that families do not resort to damaging coping } \\
\text { strategies. This should link to a livelihoods } \\
\text { recovery strategy that takes into account and } \\
\text { values equally the contributions of women and } \\
\text { men to the economy (including the care } \\
\text { economy). }\end{array}$ \\
\hline Livelihoods & $\begin{array}{l}\text { Women have lost their } \\
\text { livelihoods, which were } \\
\text { largely home-based or }\end{array}$ & $\begin{array}{l}\text { Government, } \\
\text { UN, donors, } \\
\text { NGOs/CSOs }\end{array}$ & $\begin{array}{l}\text { Livelihood actors should consult with women in } \\
\text { order to establish the best mechanisms to meet }\end{array}$ \\
\hline
\end{tabular}




\begin{tabular}{|c|c|c|c|}
\hline & $\begin{array}{l}\text { related to the cleaning and } \\
\text { selling of fish. Some women } \\
\text { have taken out high- } \\
\text { interest loans to restart } \\
\text { their businesses. }\end{array}$ & & $\begin{array}{l}\text { their food security needs and to re-establish } \\
\text { their livelihood activities. }\end{array}$ \\
\hline & $\begin{array}{l}\text { Men have lost their } \\
\text { livelihoods as they have } \\
\text { lost their boats and fishing } \\
\text { equipment. However, } \\
\text { fishing was already under } \\
\text { threat before the disaster. }\end{array}$ & $\begin{array}{l}\text { Government, } \\
\text { UN, donors, } \\
\text { NGOs/CSOs }\end{array}$ & $\begin{array}{l}\text { Further analysis and consultation are needed } \\
\text { with men and women by all livelihood sector } \\
\text { actors to decide the best course of action to } \\
\text { recover their livelihoods. Analysis is needed to } \\
\text { establish whether restoring fishing livelihoods is } \\
\text { the most appropriate course of action, or } \\
\text { whether a livelihood diversification strategy } \\
\text { would be more appropriate. }\end{array}$ \\
\hline & \multirow{4}{*}{$\begin{array}{l}\text { There is a pre-existing } \\
\text { societal belief that women } \\
\text { are secondary livelihood } \\
\text { providers in the household. } \\
\text { The emergency could offer } \\
\text { an opportunity to be } \\
\text { transformative by working } \\
\text { to change this underlying } \\
\text { belief and therefore } \\
\text { reducing inequality } \\
\text { between men and women. }\end{array}$} & Government & $\begin{array}{l}\text { Any livelihood programme established with men } \\
\text { and women should include campaign activities } \\
\text { to increase the value attributed to women's } \\
\text { work (both reproductive and productive) in order } \\
\text { to challenge gender norms. Leadership by } \\
\text { women should be encouraged in all livelihood } \\
\text { activities. }\end{array}$ \\
\hline & & UN & $\begin{array}{l}\text { The UN should work with the government to } \\
\text { design a long-term livelihood programme that } \\
\text { seeks to promote women's leadership and to } \\
\text { change societal beliefs around the role of } \\
\text { women. }\end{array}$ \\
\hline & & Donors & $\begin{array}{l}\text { Donors should ensure that actions are included } \\
\text { in any livelihood proposals to counteract } \\
\text { negative beliefs and to promote women's } \\
\text { leadership. }\end{array}$ \\
\hline & & NGOs/CSOs & $\begin{array}{l}\text { NGOs and CSOs should pilot women's } \\
\text { empowerment programmes in the livelihood } \\
\text { sector that can then be taken up by the } \\
\text { government and scaled up. Campaigns working } \\
\text { with men and women to change views on gender } \\
\text { norms should also be undertaken. NGOs can } \\
\text { work with village leaders to promote gender } \\
\text { equality. }\end{array}$ \\
\hline \multirow[t]{6}{*}{ Shelter } & $\begin{array}{l}\text { Cold conditions have been } \\
\text { reported in shelters, } \\
\text { particularly affecting } \\
\text { women, children and } \\
\text { people with disabilities, } \\
\text { who spend more time in the } \\
\text { tents. }\end{array}$ & $\begin{array}{l}\text { Government, } \\
\text { UN, donors, } \\
\text { NGOs/CSOs }\end{array}$ & $\begin{array}{l}\text { Consider distributions of blankets and } \\
\text { improvements to shelters that take into } \\
\text { consideration the different needs of men, } \\
\text { women, girls and boys. }\end{array}$ \\
\hline & $\begin{array}{l}\text { There are } 2-3 \text { families in } \\
\text { each tent, without any } \\
\text { partitions to separate one } \\
\text { family from another. }\end{array}$ & $\begin{array}{l}\text { Government, } \\
\text { UN, } \\
\text { NGOs/CSOs }\end{array}$ & $\begin{array}{l}\text { Erect partitions in tents and promote privacy. } \\
\text { Invest in earthquake-proof shelters, with co- } \\
\text { ownership by wives and husband of any shelter } \\
\text { scheme. }\end{array}$ \\
\hline & \multirow{4}{*}{$\begin{array}{l}\text { Inadequate lighting around } \\
\text { shelters represents a GBV } \\
\text { risk and makes women and } \\
\text { girls feel unsafe around } \\
\text { their shelters. All actors } \\
\text { have a responsibility to } \\
\text { integrate GBV prevention } \\
\text { into their responses, and } \\
\text { lighting is one key aspect } \\
\text { of this. }\end{array}$} & Government & $\begin{array}{l}\text { Urgently install adequate lighting around all } \\
\text { shelters. }\end{array}$ \\
\hline & & UN & $\begin{array}{l}\text { Clarify who is responsible for monitoring and } \\
\text { evaluating lighting around shelters. }\end{array}$ \\
\hline & & Donors & $\begin{array}{l}\text { Ensure that budgets for shelter include } \\
\text { sufficient lighting. }\end{array}$ \\
\hline & & NGOs/CSOs & $\begin{array}{l}\text { Monitor and evaluate perceptions of GBV risk } \\
\text { (and reported cases) before and after improved } \\
\text { lighting is installed. }\end{array}$ \\
\hline
\end{tabular}




\begin{tabular}{|c|c|c|c|}
\hline & $\begin{array}{l}\text { The population are not } \\
\text { actively participating in } \\
\text { shelter construction. }\end{array}$ & $\begin{array}{l}\text { Government, } \\
\text { UN, donors, } \\
\text { NGOs/CSOs }\end{array}$ & $\begin{array}{l}\text { Actively promote participation of the affected } \\
\text { population (women and men) in shelter design } \\
\text { and construction. There should be active and } \\
\text { meaningful participation in the response by the } \\
\text { affected population, and not just consultation. } \\
\text { The active participation of women in designing } \\
\text { and constructing shelters may be perceived as a } \\
\text { power shift, and so this dynamic should be } \\
\text { discussed and solutions developed with both } \\
\text { men and women. }\end{array}$ \\
\hline & $\begin{array}{l}\text { In some cases, the building } \\
\text { of shelters has created risk } \\
\text { e.g. in Langaleso where } \\
\text { shelters have been built on } \\
\text { rice fields prone to } \\
\text { flooding. }\end{array}$ & $\begin{array}{l}\text { Government, } \\
\text { UN, donors, } \\
\text { NGOs/CSOs }\end{array}$ & $\begin{array}{l}\text { Incorporate a comprehensive DRR strategy into } \\
\text { the shelter response, ensuring that shelters are } \\
\text { earthquake- and flood-resistant. }\end{array}$ \\
\hline & $\begin{array}{l}\text { The tents provided are not } \\
\text { friendly spaces for } \\
\text { pregnant and } \\
\text { breastfeeding women or for } \\
\text { women and men with } \\
\text { disabilities. This further } \\
\text { disadvantages people who } \\
\text { already have additional } \\
\text { vulnerabilities and restricts } \\
\text { their participation in the } \\
\text { response, as well as } \\
\text { potentially having an effect } \\
\text { on their mental health. }\end{array}$ & $\begin{array}{l}\text { Government, } \\
\text { UN, donors, } \\
\text { NGOs/CSOs }\end{array}$ & $\begin{array}{l}\text { Create spaces in the camps that are friendly to } \\
\text { women and to people with disabilities, in } \\
\text { consultation with these groups to ensure } \\
\text { appropriate location and services. Women and } \\
\text { people living with disabilities should also be } \\
\text { involved in the management of these spaces. }\end{array}$ \\
\hline \multirow[t]{4}{*}{ Education } & $\begin{array}{l}\text { There is little psychosocial } \\
\text { support available, and } \\
\text { teachers are having to take } \\
\text { on this role. }\end{array}$ & $\begin{array}{l}\text { Government, } \\
\text { UN, donors } \\
\text { and NGOs }\end{array}$ & $\begin{array}{l}\text { Psychosocial support needs to be provided for } \\
\text { school children and teachers, and teachers } \\
\text { need to be trained on how to provide this } \\
\text { support to their students. }\end{array}$ \\
\hline & \multirow[t]{3}{*}{$\begin{array}{l}\text { High daytime temperatures } \\
\text { in tents make it hard for } \\
\text { children to study. } \\
\text { Temporary schools are still } \\
\text { in use. }\end{array}$} & Government & $\begin{array}{l}\text { Ensure that tents are set up with adequate } \\
\text { ventilation and that teachers are clear on how to } \\
\text { use ventilation systems. If necessary, adjust } \\
\text { school hours to cooler times of the day, in } \\
\text { consultation with affected communities. In the } \\
\text { long term, the Ministry of Education needs to } \\
\text { invest in earthquake-proof school buildings and } \\
\text { in strategies to promote safety in schools. } \\
\text { Schools should have adequate menstrual } \\
\text { hygiene facilities to encourage attendance by } \\
\text { girls. }\end{array}$ \\
\hline & & UN & $\begin{array}{l}\text { The UN should support the government in the } \\
\text { rebuilding of earthquake-proof schools that } \\
\text { take into account the needs of both girls and } \\
\text { boys. }\end{array}$ \\
\hline & & NGOs/CSOs & $\begin{array}{l}\text { Where NGOs are providing temporary schools, } \\
\text { they should ensure that ventilation is adequate } \\
\text { and should advocate for the rebuilding of } \\
\text { permanent schools. }\end{array}$ \\
\hline Health & $\begin{array}{l}\text { There is a lack of } \\
\text { reproductive health } \\
\text { services in the camps; } \\
\text { basic healthcare is } \\
\text { available, but not }\end{array}$ & Government & $\begin{array}{l}\text { The government should ensure that reproductive } \\
\text { health services are prioritized in the response, } \\
\text { and should work with existing health services in } \\
\text { the camps to ensure that they also take into } \\
\text { account reproductive health needs. }\end{array}$ \\
\hline
\end{tabular}




\begin{tabular}{|c|c|c|c|}
\hline & \multirow{3}{*}{$\begin{array}{l}\text { reproductive healthcare. } \\
\text { Further research (which } \\
\text { was not possible in this } \\
\text { study due to time } \\
\text { constraints) could be } \\
\text { useful to develop a more } \\
\text { gendered understanding of } \\
\text { the sector, e.g. examining } \\
\text { questions such as the } \\
\text { cultural and religious } \\
\text { aspects of healthcare, } \\
\text { pregnancy, childbirth and } \\
\text { menstruation in order to } \\
\text { improve and adapt basic } \\
\text { and reproductive } \\
\text { healthcare interventions. }\end{array}$} & UN & $\begin{array}{l}\text { The UN should consider stepping in to fill the gap } \\
\text { while services are being established. }\end{array}$ \\
\hline & & Donors & $\begin{array}{l}\text { Donors in the health sector should ensure that } \\
\text { funds are earmarked for reproductive health } \\
\text { services. }\end{array}$ \\
\hline & & NGOs/CSOs & $\begin{array}{l}\text { NGOs/CSOs specializing in reproductive health } \\
\text { should work with existing basic health services } \\
\text { to establish why reproductive health services } \\
\text { are not available, and help to provide a solution. }\end{array}$ \\
\hline & \multirow{3}{*}{$\begin{array}{l}\text { Psychosocial support post- } \\
\text { trauma is not widely } \\
\text { available. This is affecting } \\
\text { people's ability to work, as } \\
\text { well as their health. }\end{array}$} & Government & $\begin{array}{l}\text { Psychosocial support should be provided in all } \\
\text { camps, ensuring that men, women, boys and } \\
\text { girls have access to services. }\end{array}$ \\
\hline & & Donors & $\begin{array}{l}\text { Donors in the health sector should ensure that } \\
\text { funds are earmarked for psychosocial health } \\
\text { services. }\end{array}$ \\
\hline & & NGOs/CSOs & $\begin{array}{l}\text { NGOs/CSOs specializing in psychosocial support } \\
\text { should fill the gap if necessary and train local } \\
\text { health centre staff in basic psychosocial } \\
\text { support. }\end{array}$ \\
\hline \multirow[t]{2}{*}{ Protection } & $\begin{array}{l}\text { GBV is a particular risk, and } \\
\text { there have been reports of } \\
\text { rape and harassment of } \\
\text { LGBTI people. There is } \\
\text { limited information about } \\
\text { women's rights, legal } \\
\text { protections and the } \\
\text { availability of paralegal } \\
\text { services. }\end{array}$ & $\begin{array}{l}\text { Government, } \\
\text { UN, donors } \\
\text { and } \\
\text { NGOS/CSOs }\end{array}$ & $\begin{array}{l}\text { All actors involved in protection need to ensure } \\
\text { the availability of reliable GBV reporting } \\
\text { mechanisms and case referral services which all } \\
\text { women, men, boys, girls and LGBTI people can } \\
\text { access. Information on women's rights, legal } \\
\text { protections and paralegal services should be } \\
\text { communicated to the affected population. }\end{array}$ \\
\hline & $\begin{array}{l}\text { There is a risk of people } \\
\text { adopting negative coping } \\
\text { strategies, such as child } \\
\text { marriage or taking out } \\
\text { high-interest loans. Due to } \\
\text { time constraints, there is } \\
\text { not sufficient information } \\
\text { to come to conclusions on } \\
\text { the exact nature and scale } \\
\text { of these coping } \\
\text { mechanisms or exactly } \\
\text { what changes have } \\
\text { occurred post-disaster. }\end{array}$ & $\begin{array}{l}\text { Government, } \\
\text { UN, donors } \\
\text { and } \\
\text { NGOS/CSOs }\end{array}$ & $\begin{array}{l}\text { Further research is recommended on negative } \\
\text { coping strategies in order to target at-risk } \\
\text { groups with appropriate actions. }\end{array}$ \\
\hline \multirow[t]{2}{*}{$\begin{array}{l}\text { Camp } \\
\text { management }\end{array}$} & \multirow{2}{*}{$\begin{array}{l}\text { Where women do not } \\
\text { participate in camp } \\
\text { management, they tend not } \\
\text { be involved in decision } \\
\text { making. Women's } \\
\text { participation is a key } \\
\text { strategy for changing } \\
\text { power dynamics. }\end{array}$} & Government & $\begin{array}{l}\text { Promote women's leadership and participation in } \\
\text { camp management, working with men where } \\
\text { necessary to raise awareness of the importance } \\
\text { and value of women's participation. }\end{array}$ \\
\hline & & NGOs/CSOs & $\begin{array}{l}\text { Advocate for women's participation and } \\
\text { leadership in all camp management committees. }\end{array}$ \\
\hline
\end{tabular}




\begin{tabular}{|c|c|c|c|}
\hline & $\begin{array}{l}\text { There is a varying amount } \\
\text { of participation by women } \\
\text { in the management of } \\
\text { public kitchens. Kitchen } \\
\text { management does not } \\
\text { significantly challenge } \\
\text { women's traditional roles in } \\
\text { society; however, where } \\
\text { participation is low even in } \\
\text { this space it is important to } \\
\text { empower women. }\end{array}$ & $\begin{array}{l}\text { Government, } \\
\text { NGOs/CSOs }\end{array}$ & $\begin{array}{l}\text { Where women are participating in public kitchen } \\
\text { management, build on this capacity to develop } \\
\text { women's leadership, and where it is lacking } \\
\text { promote women's participation and leadership } \\
\text { (after conducting a protection risk assessment). } \\
\text { Also, promote women's leadership in other areas } \\
\text { of camp management to challenge assumptions } \\
\text { around women's and men's roles. }\end{array}$ \\
\hline & $\begin{array}{l}\text { Gender-specific practical } \\
\text { needs are sometimes not } \\
\text { taken into account e.g. } \\
\text { where women are leaders, } \\
\text { men have not always } \\
\text { received razors or prayer } \\
\text { caps. }\end{array}$ & $\begin{array}{l}\text { Government, } \\
\text { UN, donors } \\
\text { and } \\
\text { NGOs/CSOs }\end{array}$ & $\begin{array}{l}\text { Ensure that the practical needs of both women } \\
\text { and men are considered in aid distributions } \\
\text { through adequatelseparate) consultation with } \\
\text { both groups. }\end{array}$ \\
\hline
\end{tabular}




\section{APPENDIX 1: SUMMARY OF KEY RESEARCH AREAS, TOOL AND METHODS USED}

\begin{tabular}{|c|c|c|c|}
\hline Areas & Key research areas & Tools & $\begin{array}{l}\text { Data and analysis } \\
\text { methods }\end{array}$ \\
\hline \multirow[t]{4}{*}{$\begin{array}{l}\text { Gender-based } \\
\text { impacts of the } \\
\text { disaster }\end{array}$} & $\begin{array}{l}\text { - Situation of women, } \\
\text { men, boys and girls } \\
\text { before and after the } \\
\text { disaster }\end{array}$ & - Time use analysis & $\begin{array}{l}\text { - } \text { In-depth interviews } \\
\text { - } \quad \text { FGDs }\end{array}$ \\
\hline & $\begin{array}{l}\text { - Gender issues in } \\
\text { emergency and } \\
\text { gender-based rights } \\
\text { fulfilment }\end{array}$ & $\begin{array}{l}\text { - Access - control profile. } \\
\text { Narrative of women and } \\
\text { vulnerable groups in } \\
\text { emergency }\end{array}$ & $\begin{array}{ll}\text { - } & \text { In-depth interviews } \\
\text { - } & \text { Observation }\end{array}$ \\
\hline & $\begin{array}{l}\text { Gender-based } \\
\text { vulnerabilities relating } \\
\text { to care roles and } \\
\text { people with disabilities }\end{array}$ & $\begin{array}{l}\text { - Narrative of women and } \\
\text { vulnerable groups in } \\
\text { emergency }\end{array}$ & $\begin{array}{ll}\text { - } & \text { In- depth interviews } \\
\text { - } & \text { FGDs } \\
\text { - } & \text { Observation }\end{array}$ \\
\hline & - Rapid care analysis & - Time use analysis & $\begin{array}{ll}\text { - } & \text { In-depth interviews } \\
\text { - } & \text { FGDs } \\
\text { - } & \text { Observation }\end{array}$ \\
\hline \multirow{3}{*}{$\begin{array}{l}\text { Gender-based } \\
\text { capacities, } \\
\text { particularly for } \\
\text { disaster } \\
\text { response and } \\
\text { also potential } \\
\text { for disaster } \\
\text { recovery }\end{array}$} & $\begin{array}{l}\text { - Women's and men's } \\
\text { capacities: } \\
\text { individual/family, } \\
\text { organization, } \\
\text { community }\end{array}$ & $\begin{array}{l}\text { Matrix of gender-based } \\
\text { capacities: individual/ } \\
\text { household level }\end{array}$ & $\begin{array}{ll}\text { - } & \text { In-depth interviews } \\
\text { - } & \text { FGDs } \\
\text { - } & \text { Observation }\end{array}$ \\
\hline & $\begin{array}{l}\text { - Women's and men's } \\
\text { organizational } \\
\text { capacities }\end{array}$ & $\begin{array}{l}\text { Matrix of gender-based } \\
\text { capacities: institutional } \\
\text { level }\end{array}$ & $\begin{array}{l}\text { - } \text { In-depth interviews } \\
\text { - } \text { FGDs } \\
\text { - } \text { Observation }\end{array}$ \\
\hline & $\begin{array}{l}\text { - Women's and men's } \\
\text { capacities }\end{array}$ & $\begin{array}{l}\text { Matrix of gender-based } \\
\text { capacities: society level }\end{array}$ & $\begin{array}{ll}\text { - } & \text { In-depth interviews } \\
\text { - } & \text { FGDs } \\
\text { - } & \text { Observation }\end{array}$ \\
\hline \multirow[t]{3}{*}{$\begin{array}{l}\text { Gender-based } \\
\text { recovery needs }\end{array}$} & $\begin{array}{l}\text { - } \text { Practical needs in } \\
\text { post-disaster recovery }\end{array}$ & $\begin{array}{l}\text { - List of practical needs } \\
\text { disaggregated by gender }\end{array}$ & $\begin{array}{l}\text { - In-depth interviews } \\
\text { - FGDs }\end{array}$ \\
\hline & $\begin{array}{l}\text { - Strategic needs in } \\
\text { post-disaster recovery }\end{array}$ & $\begin{array}{l}\text { - List of strategic needs } \\
\text { disaggregated by gender }\end{array}$ & $\begin{array}{l}\text { - In-depth interviews } \\
\text { - FGDs }\end{array}$ \\
\hline & $\begin{array}{l}\text { Recommendations for } \\
\text { the approach and key } \\
\text { recommendations }\end{array}$ & $\begin{array}{l}\text { - List of proposed } \\
\text { recommendations }\end{array}$ & $\begin{array}{l}\text { - In-depth interviews } \\
\text { - FGDs }\end{array}$ \\
\hline
\end{tabular}




\section{APPENDIX 2: CASE STUDIES OF PEOPLE WITH DISABILITIES}

1. L. is a 14-year-old girl. She suffers from a speech impairment and often needs her parents to voice her opinion. The disability has forced L. to leave school due to the difficulty she has in understanding and following instructions. In the emergency, her condition has left her in a very vulnerable position, as it is hard for her to understand instructions about evacuation routes or how to survive. Her lack of formal education also prevents her from accessing any written information, as well as the social and economic resources needed to survive.

2. S. is a 10-year-old boy. He lives at the command centre in Loli Pesua camp with his parents after the earthquake and tsunami destroyed their two-storey home, which they also used as a shop. His mother has now restarted a small business as a seller of es lilin (ice pops) and fried banana in the command centre. S.is cheerful and seems like any other child, except that he has Down syndrome and has difficulty in understanding complex information. Before the disaster, S. attended a public school close to his home but dropped out after he failed to adapt. Now, at the age of 10 , he is still unable to read or write.

3. A. is a woman around 40 years old - she doesn't know her date of birth or her exact age. She lives in Sibalaya Utara, Sigi, and is one of the hundreds of people who are currently taking refuge in the Sibalaya Utara Market camp. She has a dual disability, with difficulty in hearing and speaking. Physically, she is small and below the average height for an adult. Her attitude is a combination of feeling shy and feeling pessimistic, and her neighbours also sometimes tease her. She is the head of household after separating from her husband, but has no children. Currently, she lives in a market stall building that has been converted into a shelter.

4. There are two people with disabilities in Dusun II camp in Langaleso village. The first is a girl aged under five. Itis likely that she suffers from cerebral palsy, on the evidence of symptoms such as a slow nerve response and lack of physical movement. She depends entirely on her parents for her daily activities; her condition has increased their parenting load, particularly for her mother. The second is an 11-year-old boy. He is deaf and also suffers from vision problems, and needs a hearing aid and glasses.

5. At the Masjid Agung Palu camp there arelo people with different disabilities. They include individuals who are blind or have impaired vision, are physically disabled, are hearing-impaired or have intellectual disabilities. As many as four of these 10 people have multiple disabilities. Three of the 10 are female and seven are male, with five under 18 years old and five adults. In this camp, people with disabilities claim to have difficulty in communicating with other community members. Five of the 10 havenever gone to school. They are not involved in any social activities, and this has made them feel insecure. At present, eight of the 10 are living in dormitories provided by a religious organization specifically for people with disabilities. 


\section{APPENDIX 3: DETAILED RESULTS OF RAPID CARE ANALYSIS}

\section{Time use analysis for men lassessed in focus group discussions]}

Men's daily activity cycle at Kabonena camp: before and after the disaster

\begin{tabular}{|l|l|l|l|}
\hline \multicolumn{2}{|l|}{ Before the disaster } & \multicolumn{2}{l|}{ After the disaster } \\
\hline Time & Activity & Time & Activity \\
\hline 04.30 & Wake up, prayers & 04.30 & Wake up, prayers \\
\hline 06.30 & $\begin{array}{l}\text { Have breakfast lcoffee and } \\
\text { cake) }\end{array}$ & 05.00 & Sleep \\
\hline 07.00 & Work & 07.00 & Get up, drink coffee, breakfast \\
\hline & & 09.00 & Find a place to take a shower \\
\hline & & 10.00 & Help around the camp \\
\hline 13.00 & Lunch, break time & 13.00 & Lunch, break time \\
\hline 16.30 & Work & 14.00 & Return to the camp \\
\hline 17.00 & Return home, rest & 17.00 & Return to the tent \\
\hline 18.00 & Prayers, dinner & 18.00 & Prayers, dinner \\
\hline 19.00 & Relax, socialize & 19.00 & Relax, socialize \\
\hline 22.00 & Sleep & 22.00 & Sleep, do night watch if scheduled \\
\cline { 2 - 3 } & & & \\
\hline
\end{tabular}

Men's daily activity cycle at Loly Pesua camp: before and after the disaster

\begin{tabular}{|l|l|l|l|}
\hline \multicolumn{3}{|l|}{ Before the disaster } & \multicolumn{2}{l|}{ After the disaster } \\
\hline Time & Activity & Time & Activity \\
\hline 06.00 & Morning shower & & \\
\hline 06.30 & Take children to school & & \\
\hline 07.00 & Breakfast, drink coffee/tea & & \\
\hline 08.00 & Work & 08.00 & Get up, shower, breakfast \\
\hline & & 09.30 & Go to work or camp \\
\hline 13.00 & Rest, lunch, prayers & 13.00 & Return from work, rest, lunch \\
\hline 14.00 & Return to work & 14.00 & return to work or camp \\
\hline 17.00 & Return from work, rest, shower & 17.00 & Return from work, rest, shower \\
\hline 18.00 & Prayers together & 18.00 & Prayer \\
\hline & & 19.00 & Hang out in camp \\
\hline 20.00 & Socialize with family members & & \\
\hline 22.00 & Rest & 22.00 & Rest \\
\hline
\end{tabular}


Men's daily activity cycle at Langaleso camp: before and after the disaster

\begin{tabular}{|l|l|l|l|}
\hline \multicolumn{2}{|l|}{ Before the disaster } & \multicolumn{2}{l|}{ After the disaster } \\
\hline Time & Activity & Time & Activity \\
\hline 04.30 & Prayers, sleep & & \\
\hline 06.00 & Drink coffee, go to farm & 04.30 & Prayers \\
\hline 07.30 & Work on the farm & 06.00 & Drink coffee, smoke \\
\hline 12.00 & Rest & 07.30 & $\begin{array}{l}\text { Volunteer work, dig in the ruins, } \\
\text { access information on aid } \\
\text { distributions, gather firewood }\end{array}$ \\
\hline 14.00 & Work on the farm & 12.00 & \begin{tabular}{l} 
Rest \\
\hline 17.00
\end{tabular} \\
\hline 19.00 & Have a shower, prayers & 14.00 & $\begin{array}{l}\text { Access information on aid } \\
\text { distributions, dig for scrap metal }\end{array}$ \\
\hline 22.00 & $\begin{array}{l}\text { Dinner, rest, drink coffee, } \\
\text { watch TV, chat with wife }\end{array}$ & 17.00 & Prayers, dinner \\
\hline & Sleep & 19.00 & $\begin{array}{l}\text { Rest, hang out with neighbours } \\
\text { Do night watch, access } \\
\text { information on aid distributions }\end{array}$ \\
\hline
\end{tabular}

\section{Time use analysis for women lassessed in focus group discussions]}

Time use analysis for women at Kabonena camp: before and after the disaster

\begin{tabular}{|c|c|c|c|c|c|}
\hline \multicolumn{2}{|c|}{ Before the disaster } & \multicolumn{4}{|c|}{ After the disaster } \\
\hline \multirow[t]{2}{*}{ Time } & \multirow[t]{2}{*}{ Activity } & \multicolumn{2}{|c|}{ Already back to selling } & \multicolumn{2}{|c|}{ Have not returned to selling } \\
\hline & & Time & Activities & Time & Activities \\
\hline 03.00 & $\begin{array}{l}\text { Get up } \\
\text { Cook nasi kuning(rice) } \\
\text { Prepare food to sell }\end{array}$ & 04.30 & $\begin{array}{l}\text { Prayers, prepare } \\
\text { breakfast }\end{array}$ & 04.30 & $\begin{array}{l}\text { Prayers, prepare } \\
\text { breakfast }\end{array}$ \\
\hline 04.30 & Take shower & 06.00 & $\begin{array}{l}\text { Shower, cook lunch, } \\
\text { wash clothes/dishes, } \\
\text { clean tent, take care of } \\
\text { children }\end{array}$ & 06.00 & $\begin{array}{l}\text { Have shower, cook } \\
\text { lunch, wash } \\
\text { clothes/dishes, clean } \\
\text { tent, take care of } \\
\text { children }\end{array}$ \\
\hline 04.50 & Prayers & \multirow[t]{6}{*}{09.00} & \multirow{6}{*}{$\begin{array}{l}\text { Buy materials for selling } \\
\text { ice and snacks, prepare } \\
\text { food and ice, sell ice and } \\
\text { snacks }\end{array}$} & \multirow[t]{7}{*}{11.00} & \multirow{7}{*}{$\begin{array}{l}\text { Rest in tent, socialize } \\
\text { with neighbours, } \\
\text { particularly other women }\end{array}$} \\
\hline 05.00 & $\begin{array}{l}\text { Clean the house, } \\
\text { prepare breakfast and } \\
\text { food to sell }\end{array}$ & & & & \\
\hline 05.30 & $\begin{array}{l}\text { Go to sell food, open } \\
\text { the stall }\end{array}$ & & & & \\
\hline 06.30 & Selling & & & & \\
\hline 13.00 & Rest, prayers & & & & \\
\hline 14.00 & $\begin{array}{l}\text { Take care of children, } \\
\text { prepare lunch }\end{array}$ & & & & \\
\hline 15.00 & $\begin{array}{l}\text { Go to market to buy } \\
\text { materials for sale the } \\
\text { next day }\end{array}$ & 15.00 & $\begin{array}{l}\text { Return home from selling, } \\
\text { rest }\end{array}$ & & \\
\hline
\end{tabular}




\begin{tabular}{|l|l|l|l|l|l|}
\hline 17.00 & $\begin{array}{l}\text { Rest, afternoon shower, } \\
\text { prepare dinner }\end{array}$ & 16.00 & $\begin{array}{l}\text { Rest in tent, socialize } \\
\text { with neighbours }\end{array}$ & 17.00 & Prepare dinner, prayer \\
\hline $\begin{array}{l}18.00- \\
19.00\end{array}$ & $\begin{array}{l}\text { Prayers, dinner, wash } \\
\text { dishes }\end{array}$ & 17.00 & Prepare dinner, prayers & 19.00 & $\begin{array}{l}\text { Dinner, take care of } \\
\text { children, clean tent }\end{array}$ \\
\hline $\begin{array}{l}19.00- \\
22.00\end{array}$ & $\begin{array}{l}\text { Start cooking for selling } \\
\text { next day }\end{array}$ & 19.00 & $\begin{array}{l}\text { Dinner, take care of } \\
\text { children, clean tent }\end{array}$ & 22.00 & Sleep \\
\hline 22.00 & Sleep & 22.00 & Sleep & & \\
\hline
\end{tabular}

Time use analysis of for women at Langaleso camp: before and after the disaster

\begin{tabular}{|c|c|c|c|}
\hline \multicolumn{2}{|c|}{ Before the disaster } & \multicolumn{2}{|c|}{ After the disaster } \\
\hline Time & Activity & Time & Activity \\
\hline 04.30 & Prayers, wash, cook & 04.30 & Prayers \\
\hline 06.00 & $\begin{array}{l}\text { Prepare breakfast, clean the } \\
\text { house }\end{array}$ & 06.00 & $\begin{array}{l}\text { Cook, wash clothes and cooking } \\
\text { equipment, clean tent/house, } \\
\text { take care of children }\end{array}$ \\
\hline 07.30 & $\begin{array}{l}\text { Work on farm, as farm labourer or } \\
\text { trader }\end{array}$ & 07.30 & $\begin{array}{l}\text { Go to emergency kitchen, cook, } \\
\text { take care of children }\end{array}$ \\
\hline 12.00 & $\begin{array}{l}\text { Rest, wash clothes, prepare and } \\
\text { have lunch }\end{array}$ & 12.00 & Rest, wash, prepare lunch \\
\hline 14.00 & Work in garden & 14.00 & Clean house/tent, prepare dinner \\
\hline 17.00 & $\begin{array}{l}\text { Have shower, prayers, take care of } \\
\text { children, prepare dinner }\end{array}$ & 17.00 & $\begin{array}{l}\text { Prayers, take care of children, } \\
\text { have dinner }\end{array}$ \\
\hline 19.00 & $\begin{array}{l}\text { Dinner, wash dishes, clean the } \\
\text { kitchen, fold clothes }\end{array}$ & 19.00 & Tidy up the tent \\
\hline 22.00 & Prepare food to sell & & $\begin{array}{l}\text { Rest in the tent, take care of } \\
\text { children }\end{array}$ \\
\hline 23.00 & Sleep & 22.00 & Sleep \\
\hline
\end{tabular}

Time use analysis for women at Loly Pesua camp: before and after the disaster

\begin{tabular}{|c|c|c|c|}
\hline \multicolumn{2}{|c|}{ Before the disaster } & \multicolumn{2}{|c|}{ After the disaster } \\
\hline Time & Activity & Time & Activity \\
\hline 05.00 & Get up, boil water, cook rice for breakfast & 05.00 & Prayers \\
\hline 06.00 & $\begin{array}{l}\text { Prepare breakfast, prepare children for } \\
\text { school }\end{array}$ & & Take care of children \\
\hline 06.30 & Wash clothes and dishes, clean house & 06.30 & Clean the tent, wash dishes, cook breakfast \\
\hline 07.00 & Prepare husband's breakfast & & \\
\hline 08.00 & $\begin{array}{l}\text { Take care of young children, bathe } \\
\text { children }\end{array}$ & 09.00 & Queue to have a shower and bathe children \\
\hline 09.00 & $\begin{array}{l}\text { Prepare ingredients and equipment to } \\
\text { make fried banana }\end{array}$ & 10.00 & Take care of children \\
\hline 10.00 & Prepare husband's lunch & 11.00 & Take a rest \\
\hline 13.00 & Rest, have lunch, prayers & 15.00 & Have a shower \\
\hline 14.00 & Take care of children & 16.00 & Socialize with other camp residents \\
\hline 15.00 & Prepare food to sell & & \\
\hline 15.30 & Sell fried banana at the beach & & \\
\hline 18.00 & $\begin{array}{l}\text { Come home from work, prayers, have } \\
\text { shower, wash cooking utensils }\end{array}$ & 18.00 & Rest, clean the tent, take care of the children \\
\hline
\end{tabular}




\begin{tabular}{|l|l|l|l|}
\hline 19.00 & $\begin{array}{l}\text { Take care of children, help them with their } \\
\text { studies }\end{array}$ & 19.30 & Dinner \\
\hline 20.30 & Watch TV & 20.00 & Rest \\
\hline 22.00 & Sleep & 21.00 & Sleep \\
\hline
\end{tabular}

Daily activity cycles before the disaster: girls and boys (aged 8-18) (assessed in focus group discussions]

\begin{tabular}{|c|c|c|}
\hline \multirow[t]{2}{*}{ Time } & \multicolumn{2}{|l|}{ Activity } \\
\hline & Girls & Boys \\
\hline 06.00 & Wake up & \\
\hline 06.10 & Sweep the house & \\
\hline 06.20 & Wash dishes & Wake up \\
\hline 06.30 & Have a shower & Have a shower \\
\hline 06.45 & Go to school & Go to school \\
\hline $07.15-16.00$ & Study at school & Study at school \\
\hline $16.10-17.00$ & Rest & Rest \\
\hline $17.00-18.00$ & Sweep, wash dishes, cook & Play football \\
\hline $18.00-20.00$ & Have a shower, prayers, eat & Have a shower, prayers, eat \\
\hline $20.00-22.00$ & $\begin{array}{l}\text { Hang out with friends, do homework } \\
\text { assignments, hang out with family, watch } \\
\text { TV }\end{array}$ & Hang out \\
\hline $22.00-05.00$ & Sleep & Sleep \\
\hline
\end{tabular}

Daily activity cycles after the disaster: girls and boys

\begin{tabular}{|l|l|l|}
\hline \multirow{2}{*}{ Time } & Activity & Boys \\
\cline { 2 - 3 } & Girls & \\
\hline 06.30 & Wake up & Wake up, have shower \\
\hline 06.35 & Have shower & Go to school \\
\hline 07.00 & Go to school & Study at school \\
\hline 07.15 & Study at school & Rest \\
\hline 13.15 & Rest & Gather firewood, fetch water \\
\hline 15.30 & Wash dishes, cook & \\
\hline 17.00 & Hang out with friends, have shower & Prayers, eat, hang out \\
\hline 17.30 & Prayers, eat, quiet time at the camp & Sleep \\
\hline 21.00 & Sleep & \\
\hline
\end{tabular}

Time use analysis for female-headed households (assessed in FGD)

\begin{tabular}{|l|l|l|l|}
\hline \multicolumn{2}{|l|}{ Before the disaster } & \multicolumn{2}{l|}{ After the disaster } \\
\hline Time & Activity & Time & Activity \\
\hline 03.00 & Wake up, go to the market & & \\
\hline 04.00 & Selling at Masomba market & 05.00 & Wake up, prayers \\
\hline & & 06.00 & Cook, clean up the tent, wash \\
\hline & & 08.00 & $\begin{array}{l}\text { Gather at the tent, help at the emergency } \\
\text { kitchen }\end{array}$ \\
\hline 13.00 & Rest & 12.00 & Rest \\
\hline 14.00 & Work on farm & 14.00 & Gather items from ruins \\
\hline
\end{tabular}




\begin{tabular}{|l|l|l|l|}
\hline 17.00 & $\begin{array}{l}\text { Rest, pray, cook, eat dinner, chat } \\
\text { with family }\end{array}$ & $\begin{array}{l}\text { Have a shower, eat dinner, prayers, clean up } \\
\text { the tent, rest }\end{array}$ \\
\hline 20.00 & Prepare things to sell the next day & 22.00 & Sleep \\
\hline 23.00 & Sleep & & \\
\hline
\end{tabular}

Time use analysis for a woman with a disability (individual interview)

\begin{tabular}{|l|l|l|l|}
\hline \multicolumn{2}{|l|}{ Before the disaster } & After the disaster \\
\hline Time & Activities & Time & Activities \\
\hline 06.00 & Wake up, wash dishes & 05.30 & $\begin{array}{l}\text { Queue to collect clean water from the tap } \\
\text { in the camp }\end{array}$ \\
\hline 07.30 & Have shower & 07.00 & Return to tent \\
\hline 08.00 & $\begin{array}{l}\text { Clean the house, help mother with } \\
\text { cooking }\end{array}$ & 08.00 & Have shower, wash clothes, breakfast \\
\hline 10.00 & Breakfast & 11.00 & Help mother clean damaged house \\
\hline 10.30 & Rest, watch TV & 14.00 & Back to the camp \\
\hline 13.00 & Take a nap & 14.30 & Clean the tent \\
\hline 16.00 & $\begin{array}{l}\text { Clean the house, hang out on the } \\
\text { terrace }\end{array}$ & 15.00 & Rest, take a nap \\
\hline 17.30 & Have shower & 17.00 & Have shower \\
\hline 19.30 & Rest, watch TV & $18.00-$ & Rest \\
\hline 20.00 & Sleep & 22.00 & Sleep \\
\hline
\end{tabular}

Time use analysis for a woman with a disabled family member (individual interview)

\begin{tabular}{|c|c|c|c|}
\hline \multicolumn{2}{|c|}{ Before the disaster } & \multicolumn{2}{|c|}{ After the disaster } \\
\hline Time & Activity & Time & Activity \\
\hline 05.00 & Prayers, cook & 04.00 & Prayers, cook, clean up the tent \\
\hline 07.00 & $\begin{array}{l}\text { Clean the house, take care of } \\
\text { disabled children }\end{array}$ & 07.00 & $\begin{array}{l}\text { Wash clothes, tidy the tent, take care of } \\
\text { disabled children }\end{array}$ \\
\hline 11.00 & Prepare lunch & 10.00 & $\begin{array}{l}\text { Spend time with other women at } \\
\text { emergency kitchen while watching } \\
\text { children }\end{array}$ \\
\hline 12.00 & Rest & 12.00 & Rest \\
\hline \multirow[t]{2}{*}{14.00} & $\begin{array}{l}\text { Take care of children, tidy the house, } \\
\text { prepare dinner }\end{array}$ & 15.00 & Tidy up the tent, take care of children \\
\hline & & 16.00 & Queue for dinner at emergency kitchen \\
\hline 17.00 & $\begin{array}{l}\text { Prayers, dinner, chat with family, } \\
\text { watch TV }\end{array}$ & 17.00 & $\begin{array}{l}\text { Have shower, dinner, take care of children, } \\
\text { gather with family at the tent }\end{array}$ \\
\hline 22.00 & Sleep & 21.00 & Sleep \\
\hline
\end{tabular}

Time use analysis for transgender person: before and after the disaster (individual interview)

\begin{tabular}{|l|l|l|l|}
\hline \multicolumn{2}{|l|}{ Before the disaster } & \multicolumn{2}{l|}{ After the disaster } \\
\hline Time & Activity & Time & Activity \\
\hline 05.00 & $\begin{array}{l}\text { Prayers, help mother in the } \\
\text { kitchen, clean up the house, } \\
\text { cook }\end{array}$ & 05.00 & Prayers, clean the tent \\
\hline
\end{tabular}




\begin{tabular}{|c|c|c|c|}
\hline 08.00 & Go to the rice field & 08.00 & $\begin{array}{l}\text { Hang out with other people, do } \\
\text { voluntary work, collect water, gather } \\
\text { firewood for emergency kitchen }\end{array}$ \\
\hline 12.00 & $\begin{array}{l}\text { Take a bath, prayers, rest, } \\
\text { lunch }\end{array}$ & 12.00 & Rest \\
\hline 14.00 & Go to the rice field & 14.00 & $\begin{array}{l}\text { Hang out with other people, help with } \\
\text { aid distributions }\end{array}$ \\
\hline 17.00 & $\begin{array}{l}\text { Have a shower, prayers, help } \\
\text { prepare dinner, watch TV }\end{array}$ & 17.00 & Have a shower, prayers, have dinner \\
\hline 21.00 & Sleep & 21.00 & Sleep \\
\hline
\end{tabular}


1 AHA Centre (2018). Situation Update No. 15. 26 October 2018. https://ahacentre.org/wpcontent/uploads/2018/10/AHA-Situation Update-no15-Sulawesi-EQ-rev.pdf (accessed 13 March 2019)

2 Inter-Agency Standing Committee (IASC) (2017). The Gender Handbook for Humanitarian Action. https://interagencystandingcommittee.org/gender-and-humanitarian-action/content/iasc-genderhandbook-humanitarian-action-2017

3 BPS - Statistics of Sulawesi Tengah Province (2017). ProvinsiSulawesi Tengah Dalam Angka2017 / Sulawesi Tengah Province in Figures 2017. https://sulteng.bps.go.id/publication/2017/08/11/355b7acc700bd2e89afd0084/provinsi-sulawesitengah-dalam-angka-2017.html laccessed 17 November 2018)

4 BPS - Statistics of Sulawesi Tengah Province (2017). Statistik Kesejahteraan Rakyat Provinsi Sulawesi Tengah 2017 .https://sulteng.bps.go.id/publication/2017/12/29/dcac0d2c3da0c30cbd7848f6/statistikkesejahteraan-rakyat-provinsi-sulawesi-tengah-2017.html laccessed 22 November 2018)

5 Ministry of Health Regulation No 1357/Menkes/SK/XII/2001 on Minimum Standard of Disaster Emergency Response (SK No 1357/Menkes/SK/XII/2001 Tentang Standar Minimal Penanggulangan Masalah Kesehatan Akibat Bencana dan Penanganan Pengungsil.

6 Oxfam and WEDC, Loughborough University (2018). Lighting, WASH and Gender-Based Violence in Camp Settings: Literature review.

https:// oxfamilibrary.openrepository.com/bitstream/handle/10546/620606/rr-lighting-sanitationliterature-review-211218-en.pdf?sequence=48isAllowed=y. D0l: http://dx.doi.org/10.21201/2018.3620 (accessed 29 March 2019)

7 BNPB (2018). Loss and Damage of Disaster in Central Sulawesi Reach 13,82 Trillion Rupiah. 22 October 2018). https://bnpb.go.id/en/loss-and-damage-of-disaster-in-central-sulawesi-reach-1382-trillion-rupiah

8 BBC News Indonesia (9 0ctober 2018). https://www.bbc.com/indonesia/indonesia-45781643 laccessed 21 October 2018)

9 Sicca, P. S. (2018, October 21). BNPB: Kerugian \& Kerusakan Gempa di Sulteng Capai Rp13,82 Triliun. Tirto.id. https://tirto.id/bnpb-kerugian-amp-kerusakan-gempa-di-sulteng-capai-rp1382-triliun-c8dX laccessed 21 October 2018]

10 IASC (2017). The Gender Handbook for Humanitarian Action, op. cit.

11 Bappenas/UNICEF (n.d.) SDG untuk Anak-Anak di Indonesia. Profil singkat provinsi: Sulawesi Tengah.https://sdg4children.or.id/wp-content/uploads/2018/05/Bahasa-Sulawesi-Tengah-lowres2.pdf laccessed 14 November 2018)

12 BPS - Statistics of Sulawesi Tengah Province (2017). ProvinsiSulawesi Tengah Dalam Angka2017 / Sulawesi Tengah Province in Figures 2017, op. cit.; BPS - Statistics of Sulawesi Tengah Province (2017). Statistik Kesejahteraan Rakyat Provinsi Sulawesi Tengah 2017, op. cit.

13 For further information on sex ratios in South-East Asia, see World Health Organization (2019). Sex Ratio. http://www.searo.who.int/entity/health situation trends/data/chi/sex-ratio/en/

14 From Bappenas/Direktur Perlindungan dan Kesejahteraan Masyarakat (2015). Implementasi Penyelenggaraan Kesejahteraan Sosial untuk Penyandang Disabilitas Berat. Paper presented at Pukat UGM on Akuntabilitas Bantuan Kesejahteraan Sosial bagi Penyandang Disabilitas Berat, Jakarta, 10 August 2015. See also Adioetomo, S.M, D. Mont and Irwanto. (2014). Persons with Disabilities in Indonesia: Empirical Facts and Implications for Social Protection Policies, table 4.4. Jakarta, Indonesia, Demographic Institute, Faculty of Economics, University of Indonesia, in collaboration with Tim Nasional Percepatan Penanggulangan Kemiskinan (TNP2K). Jakarta, Indonesia. http://www.tnp2k.go.id/images/uploads/downloads/Disabilities\%20report\%20Final\%20sept2014\%20(1)1.pdf

15 UNDP (2018). Human Development Reports. http://hdr.undp.org/en/countries/profiles/IDN laccessed 28 March 2019)

16 Ibid.

17 Pembangunan Manusia Berbasis Gender 2016, p.39. https://www.kemenpppa.go.id/lib/uploads/list/4f9aabuku-pmbg-2016-min.pdf; Kementerian Pemberdayaan Perempuan dan Perlindungan Anak, 2017. 
18 D. Fatimah (2012). Refused to Surrender: Gender, Vulnerability and Agency in Disaster. Aksara-OxfamSasakawa Foundation.

19 lbid.

20 AHA Centre (2018). Situation Update No. 15. 26 October 2018, op. cit.

21 Harususilo, Y. E. (2018, October 14). Ini Data Terbaru, Jumlah Sekola Terdampak Bencana Sulawesi Tengah. Kompas. https://edukasi.kompas.com/read/2018/10/14/14290321/ini-data-terbaru-jumlah-sekolahterdampak-bencana-sulawesi-tengah. Figures from Provincial Government Report on Disaster in Central Sulawesi Per Dec 20th, 2018 Laporan Finalisasi Data dan Informasi Bencana Gempa Bumi, Tsunami dan Likuifaksi di Sulawesi Tengah Per Tanggal 20 Des 2018). PowerPoint presentation: https://www.humanitarianresponse.info/sites/www.humanitarianresponse.info/files/documents/files/la p ke gub 20 des 2018.pdf

22 Chipfupa, U. et al. (2018). Rapid Care Analysis: Training for Managers. Oxfam. https://oxfamilibrary.openrepository.com/bitstream/handle/10546/620449/ml-rca-training-formanagers-slides-260318-en.pdf;jsessionid=BAC33676BFD9CE3F2E61626AE9CBD1B5? sequence =1. DOI: http://dx.doi.org/10.21201/2017.1862 (accessed 12 November 2018)

23 Ministry of Health Regulation No 1357/Menkes/SK/XII/2001 on Minimum Standard of Disaster Emergency Response, op. cit.

24 H. Cipto. (2018, October 16). Anak Korban Bencana Sulteng Diperkosa 3 Pemuda di Makassar. Kompas. https://regional.kompas.com/read/2018/10/16/21075921/anak-korban-bencana-sulteng-diperkosa-3pemuda-di-makassar

25 BPS - Statistics of Sulawesi Tengah Province (2017). ProvinsiSulawesi Tengah Dalam Angka2017 / Sulawesi Tengah Province in Figures 2017, op. cit.; BPS - Statistics of Sulawesi Tengah Province (2017). Statistik Kesejahteraan Rakyat Provinsi Sulawesi Tengah 2017, op. cit.

26 Ministry of Health Regulation No 1357/Menkes/SK/XII/2001 on Minimum Standard of Disaster Emergency Response, op. cit.

27 Oxfam and WEDC, Loughborough University (2018). Lighting, WASH and Gender-Based Violence in Camp Settings, op. cit. 


\section{ACKNOWLEDGEMENTS}

\section{Rapid gender analysis research team}

This gender analysis is a collaborative piece of work between Oxfam and humanitarian networking partners (JMK), including two local organizations, LBH APIK Palu and PKBI Palu, who worked on collecting the data and writing the field notes. The process was coordinated by Dati Fatimah, a gender consultant for JMK-Oxfam, who also developed the rapid assessment tools and wrote the first draft of the report. The English version of the report was finalized by Fiona Roberts, a gender consultant for Oxfam. Key inputs were contributed by Risa Yudhiana, Gender Coordinator for the Central Sulawesi Response for Oxfam, and Tess Dico-Young, Global Humanitarian Gender Adviser for Oxfam.

\section{Oxfam Research Reports}

Oxfam Research Reports are written to share research results, to contribute to public debate and to invite feedback on development and humanitarian policy and practice. They do not necessarily reflect Oxfam policy positions. The views expressed are those of the author and not necessarily those of Oxfam.

For more information, or to comment on this report, email Julie Lafrenière: julie.lafrenieredoxfam.org

(c) Oxfam International July 2019

This publication is copyright but the text may be used free of charge for the purposes of advocacy, campaigning, education, and research, provided that the source is acknowledged in full. The copyright holder requests that all such use be registered with them for impact assessment purposes. For copying in any other circumstances, or for re-use in other publications, or for translation or adaptation, permission must be secured and a fee may be charged. Email policyandpractice@oxfam.org.uk

The information in this publication is correct at the time of going to press.

Published by Oxfam GB for Oxfam International under ISBN 978-1-78748-453-5 in July 2019. D0I: $10.21201 / 2019.4535$

Oxfam GB, Oxfam House, John Smith Drive, Cowley, Oxford, OX4 2JY, UK.

\section{OXFAM}

Oxfam is an international confederation of 19 organizations networked together in more than 90 countries, as part of a global movement for change, to build a future free from the injustice of poverty. Please write to any of the agencies for further information, or visit www.oxfam.org

Oxfam America (www.oxfamamerica.org)

Oxfam Australia (www.oxfam.org.au)

Oxfam-in-Belgium (www.oxfamsol.be)

Oxfam Brasil (www.oxfam.org.br)

Oxfam Canada (www.oxfam.ca)

Oxfam France (www.oxfamfrance.org)

Oxfam Germany (www.oxfam.de)

Oxfam GB (www.oxfam.org.uk)

Oxfam Hong Kong (www.oxfam.org.hk)

Oxfam IBIS (Denmark) (www.oxfamibis.dk)

Observer:

KEDV (Oxfam Turkey)
Oxfam India (www.oxfamindia.org)

Oxfam Intermón (Spain) (www.oxfamintermon.org)

Oxfam Ireland (www.oxfamireland.org)

Oxfam Italy (www.oxfamitalia.org)

Oxfam Mexico (www.oxfammexico.org)

Oxfam New Zealand (www.oxfam.org.nz)

Oxfam Novib (Netherlands) (www.oxfamnovib.nl)

Oxfam Québec (www.oxfam.qc.ca)

Oxfam South Africa (www.oxfam.org.za) 